\title{
The Absence of the Corporation in Islamic Law: Origins and Persistence
}

\author{
Timur Kuran* \\ Department of Economics \\ University of Southern California, \\ Los Angeles, CA 90089-0253, USA \\ (213) 740-2102・ kuran@usc.edu
}

February 28, 2006

\begin{abstract}
Classical Islamic law recognizes only natural persons; it does not grant standing to corporations. This article explores why Islamic law did not develop a concept akin to the corporation, or borrow one from another legal system. It also identifies processes that delayed the diffusion of the corporation to the Middle East even as its role in the global economy expanded. Community building was central to Islam's mission, so early Muslim jurists had no use for a concept liable to facilitate factionalism. Services with large setup costs and expected to last indefinitely were supplied through the waqf, an unincorporated trust. The waqf thus absorbed resources that might otherwise have stimulated an incorporation movement. Partly because the waqf spawned constituencies committed to preserving its key features, until modern times private merchants and producers who stood to profit from corporate powers were unable to muster the collective action necessary to reform the legal system. For their part, Muslim rulers took no initiatives of their own to supply the corporate form of organization, because they saw no commercial or financial organizations worth developing for the sake of boosting tax revenue.
\end{abstract}

Keywords: Islam, Middle East, development, partnership, joint-stock company, corporation, organization, individualism, law.

JEL classifications: N25; N85; K22; P51; O53.

* Grants from the Earhart Foundation and the Metanexus Institute, along with a fellowship of the John Simon Guggenheim Memorial Foundation, supported successive drafts of this essay. Part of the work was conducted during the 2004-05 academic year, when I held a visiting professorship in economics at Stanford University. Ali Akyıldız, Hania Abou Al-Shamat, Ann Carlos, Michael Cook, Metin Coşgel, Murat Çizakça, Avner Greif, Ron Harris, Saumitra Jha, Daniel Klerman, Reinier Kraakman, Naomi Lamoreaux, Zafer Toprak, Avram Udovitch, and Frank Vogel provided helpful feedback, and Sinan Birdal supplied indispensable research assistance. 
The year 1851 saw the founding of the first predominantly Muslim-owned joint-stock company of the Ottoman Empire: the Şirket-i Hayriye marine transportation company, literally the "Auspicious Company." Headquartered in Istanbul, its ownership was divided into 2,000 tradable shares. At the time, the empire was just beginning to install the requisite legal infrastructure. Commercial courts established to enforce the newly adopted French commercial code were in their infancy, and the opening of an organized stock exchange was not even on the drawing board. Nevertheless, Şirket-i Hayriye began operation under the patronage of sultan Abdülmecit, its largest shareholder. The company's remaining shares were purchased by high government officials, almost all Turks, and a few prominent financiers, mostly Armenians. ${ }^{1}$

For lack of a suitable Turkish word, Abdülmecit characterized Şirket-i Hayriye through a neologism derived from the French "compagnie" and English "company": "kumpaniye." What was his motive for favoring an organizational form alien to Islamic law, the traditional basis for commercial contracts? The Ottoman economy was now dominated, he observed, by large and permanent enterprises, all owned and operated by foreigners and minorities; it was time for Turks and other Muslims to join the trend of pooling resources within kumpaniyes. ${ }^{2}$ This call for organizational transformation signals that Ottoman elites of the mid-nineteenth century considered partnerships based on classical Islamic law ill-suited to the emerging banking, mass transportation, and manufacturing sectors. Evidently they understood that Islamic contract law, generally unchanged since the tenth century, did not measure up to the organizational forms now dominating the global economy. ${ }^{3}$

From the standpoint of the region's organizational development, Şirket-i Hayriye's key contribution lies in the tradability of its shares. A traditional Islamic partnership becomes null and void at the withdrawal, incapacitation, or death of even a single partner. Wherever commerce was conducted under Islamic law, this vulnerability had discouraged investment in large and long-lasting

\footnotetext{
${ }^{1}$ Eser Tutel, Şirket-i Hayriye (Istanbul 1997), 18-24; Murat Koraltürk, "Kentleşme, kentiçi ulaşım, İstanbul ve Şirket-i Hayriye'nin kuruluşu,” 10 Marmara Üniversitesi İktisadi ve İdari $\dot{I}$ limler Fakültesi Dergisi 97-101 (1995).

${ }^{2}$ Haydar Kazgan, Osmanl1'dan Cumhuriyet'e şirketleşme (Istanbul 1991), 39, 72; Ali Akyıldız, Ottoman securities (Istanbul 2001), 19, 48-51; Koraltürk, "Kentleşme," 97-101. Two leading reformers of the age, Fuat Paşa and Cevdet Paşa, appear to have been Şirket-i Hayriye’s brainchildren. See the latter's Tezâkir, 1 (Istanbul 1986 ed.), 12-13 (orig. ed. 1855-95).

${ }^{3}$ The mid-1850s saw a parallel development in Egypt, where the khedive Said Pasha chartered two steamship companies whose shares were bought mostly by Egyptian dignitaries. See David Landes, Bankers and pashas: international finance and economic imperialism in Egypt (Cambridge, Mass. 1958), 83-84, 149-54.
} 
ventures. $^{4}$ Authorized to issue tradable shares, Şirket-i Hayriye could survive changes in membership; the shares of exiting partners would simply switch hands, without recontracting. As significant, however, is that Şirket-i Hayriye was not declared a corporation. Established as an unincorporated joint-stock company, it lacked legal personhood. Why the sultan did not charter Şirket-i Hayriye as the first Ottoman-recognized corporation is unknown. It is clear, however, that a corporate charter would have lacked immediate practical value, because the empire's Islamic courts, even its nascent secular courts, lacked familiarity with the corporation. By contrast, the tradability of Şirket-i Hayriye shares was a credible characteristic, for Istanbul and a few other cities already had bustling informal markets in the shares of foreign companies.

One benefit of legal personhood, the critical characteristic of a corporation, is the simplification of litigation. Another is that it shields jointly held assets from the liabilities of individual shareholders. Critical here is a distinction between "owner shielding" (limited liability for shareholders) and "entity shielding" (limited liability for the company itself). ${ }^{5}$ An unincorporated joint-stock company and certain forms of Islamic partnership could provide owner shielding; each could protect the personal assets of an individual partner from the creditors of other partners. But neither offered entity shielding. Precisely because Şirket-i Hayriye lacked entity shielding, the creditors of a single shareholder could force it to liquidate. Only if established as an entity with legal standing and assets of its own - as a corporation — would it have enjoyed both forms of protection.

Şirket-i Hayriye benefitted, of course, from Abdülmecit's patronage. Knowing of Abdülmecit's personal commitment to its success, the creditors of a shareholder would have thought twice before pursuing its dissolution. Unincorporated joint-stock companies lacking sultanic patronage would have been more vulnerable and, hence, they would have found it more difficult to raise capital. Indeed, in the half-century following the founding of Şirket-i Hayriye the kumpaniyes established in the Ottoman Empire were mostly foreign corporations with headquarters in London or Paris, and their major disputes were settled in foreign courts. ${ }^{6}$ Ottoman corporations were owned

\footnotetext{
${ }^{4}$ Timur Kuran, "The Islamic commercial crisis: institutional roots of economic underdevelopment in the Middle East," 63 J. Econ. Hist. 414-46 (2003).

${ }^{5}$ Henry Hansmann, Reinier Kraakman \& Richard Squire, "Law and the rise of the firm," Harvard Law Rev. (2006), in press.

${ }^{6}$ The same pattern held in Egypt, where until the 1920s most heavily capitalized companies consisted of corporations headquartered abroad. See Robert L. Tignor, "The introduction of modern banking into Egypt, 1855-1920" 15 Asian and African Stud. 103-22 (1981).
} 
overwhelmingly by non-Muslims enjoying foreign legal protection. ${ }^{7}$ The explosion in domestic, and particularly Muslim, kumpaniye formation that Abdülmecit hoped to trigger through a visible prototype occurred only after 1908 , when the Ottoman parliament passed a law of corporations. ${ }^{8}$ This history accords with the view, derived from experiences elsewhere, that the unincorporated jointstock company is an inferior substitute for the business corporation. ${ }^{9}$

This article seeks to unlock the mystery of why the corporation entered the Middle Eastern menu of organizational options only recently, in the twentieth century. The task may be divided into three subtasks. The first is to explain why during its formative centuries Islamic law closed itself off to the corporation. The corporation need not have been invented from scratch, for it was present, if in rudimentary form, in Roman law, from which other concepts were borrowed. The second subtask is to determine why corporate entities or similarly functioning institutions did not emerge after the first few Islamic centuries. This challenge requires consideration of how the Middle East organized activities that in the West became the domain of corporations. It also involves determining why no demand arose for developing the corporate form. And the third is to explain why, after western Europe started to make increasing use of the corporation and to demonstrate its tangible advantages, this organizational form was not transplanted to the Middle East.

The outlined agenda recognizes that to document the absence of the corporation in early

${ }^{7}$ Zafer Toprak, Milli iktisat-milli burjuvazi (Istanbul 1995), 83-87. Aky1ld1z, Ottoman securities, 93-185, lists the founders and organizational form of 46 companies established in this period. Of this group, which includes all of the largest, 43 were founded as corporations primarily, and often exclusively, by foreigners and foreign-protected local minorities; for some purposes, therefore, they had access to foreign courts. Of the remaining three, one was Şirket-i Hayriye. The second, Şirket-i Hayriye-i Hamidiye, was another maritime transport company founded in 1906 under imperial patronage as a corporation. The third, the Karamürsel Fez and Broadcloth Company, was established in 1891 by a group composed entirely of Muslim Turks, as a "komandit" with tradable shares (a form of unincorporated jointstock company). It is significant that the only privately established company with majority-Muslim ownership is also the only one that lacked legal personhood. On the legal advantages of minorities, see Timur Kuran, "The economic ascent of the Middle East's religious minorities: the role of Islamic legal pluralism ,” 33 J. Legal Stud. sects. 2-3, 10-13 (2004).

${ }^{8}$ Toprak, Milli iktisat, chap. 7; Zafer Toprak, İttihad-Terakki ve cihan harbi: savaş ekonomisi ve Türkiye'de devletçilik, 1914-1918 (Istanbul 2003), chap. 3; Aky1ld1z, Ottoman securities, 186-301, lists 58 traded companies established between 1908 and 1920. Of this group, 56 were corporations, including 28 founded exclusively by Muslims and 10 founded by confessionally mixed groups. The passage of a law of corporations marks a turning point also in the formation of non-profit organizations. Whereas 36 non-profit organizations (derneks) were founded in Istanbul in the decade leading to 1907,438 were founded in the subsequent decade [Mehmet Ö. Alkan, "1856-1945, İstanbul'da sivil toplum kurumları: toplumsal örgütlenmenin gelişimi,” in Ahmet N. Yücekök, İlter Turan \& Mehmet Ö. Alkan (eds.), Tanzimattan günümüze İstanbul'da sivil toplum kuruluşlar1, 79-145, at 144 (Istanbul 1998)]. See also Nadir Özbek, Osmanl1 İmparatorlu $\breve{\mathrm{g} u}$ 'nda sosyal devlet: siyaset, iktidar ve meşruiyet, 1876-1914 (Istanbul 2002), chaps. 8-10.

${ }^{9}$ Hansmann, Kraakman \& Squire, "Rise of the firm," in press; Robert B. Ekelund, Jr. \& Robert D. Tollison, Politicized economies: monarchy, monopoly, and mercantilism (College Station, Tex. 1997), 209-16; Ron Harris, Industrializing English law: entrepreneurship and business organization, 1720-1844 (Cambridge 2000), 152-67, 230-86. 
Islam will not amount to an explanation of its continued absence for more than a millennium. Given a demand for organizational innovation, constraints rooted in initial conditions may be overcome. It will not do to invoke Islam's alleged traditionalism, moderation, or fatalism, all concepts often invoked as elements of a fixed social order. ${ }^{10}$ Societies governed under Islamic law have enjoyed periods of remarkable institutional dynamism; in regard to economic institutions, the eighth and ninth centuries saw revolutionary developments. And in certain areas, such as tax collection and military strategy, innovations and cross-cultural borrowings never ceased. Evidently, precedents of one sort or another were less constraining in some domains than in others. This is why the absence of the corporation is not attributable to some general or immutable characteristic of Islam.

I start with the pre-Islamic origins of the corporation and then explore the emergence of formal corporations in western Europe during the period when the Middle East witnessed the development of classical Islamic law. These two preliminary investigations are followed by analysis of the political and economic considerations that shaped the organizational elements Islamic law, with particular attention to the waqf, Islam's organizational alternative to the corporation. The remainder of the paper explores, from various angles, why Middle Eastern organizational forms that carried certain corporate characteristics did not spawn an indigenous corporate tradition and why, until modern times, the Middle East did not borrow the corporate form from the West.

\section{Roman Origins}

The association of individuals into groups pursuing a common goal extends to time immemorial. So does the concept of a collective entity, critical to the family and the state. Under the Romans, who developed this concept further, the state was empowered to hold property and transact with natural individuals as though it was itself a person. ${ }^{11}$ Collectively held Roman tax farms could outlive their individual partners; organized as special partnerships called societas publicanorum, they separated ownership from management, had representatives who acted for the company as a unit, and allowed

\footnotetext{
${ }^{10}$ It is common in academic discourses to treat traditionalism, or some similar attitude, as an independent variable that explains Middle Eastern patterns such as low scientific creativity and economic underdevelopment, rather than a dependent variable explicable through other factors. For an example from the mid-twentieth century, see Gustave E. Von Grunebaum, Medieval Islam: a study in cultural orientation, $2^{\text {nd }}$ ed. (Chicago 1953); and for a recent example, Mehmet Genç, Osmanlı İmparatorluğ unda devlet ve ekonomi (Istanbul 2000), especially chaps. 3-4, 21. Genç considers traditionalism a key element of the Ottoman economic mind. Some of his followers link this mental orientation to verses of the Qur'an that counsel moderation.

${ }^{11}$ Arthur K. Kuhn, The law of corporations (New York 1912), 17-18.
} 
the trading of their shares. ${ }^{12}$ Corpus Juris Civilis, the law code compiled during the reign of Justinian (527-65), allows the imperial treasury to sue and be sued in court. ${ }^{13}$ However, not even Justinian's code articulated a precise definition of the corporation, to say nothing of identifying its rights and obligations in general terms. It does not elucidate the relationship between the ensemble and its members. It does not specify whether the collective rights enshrined in a corporation come from a public charter or the will of its founders. ${ }^{14}$ Even the terminology used in the code (universitas, collegium, persona) is nebulous.

These ambiguities betray the conflicting motives of Roman officials. Allowing groups to have representatives, own property jointly, distinguish between personal and collective property, and have a collective life beyond the lives of its individual members could make society more productive, enhance general satisfaction with the political system, and enlarge the tax base. However, the very same capabilities might also undermine political stability by facilitating the organization of disgruntled collectivities. Jurists who wanted incorporation to be a state-granted privilege tried, in effect, to balance these considerations. ${ }^{15}$ From their standpoint, regulated incorporation had the further advantage of enabling the state, as the issuer of corporate charters, to appropriate some of the consequent rents. In opposing all permanent associations other than the family and the state, these jurists rejected freedom of association.

Nevertheless, over the next half-millennium diverse private associations_-burial clubs, craft guilds, charitable societies, cults, churches, monasteries - demanded and gained general recognition as corporations in lands under the control of the eastern Roman Empire and, more prominently, in former territories of the western Roman Empire. To varying degrees, each exercised self-governance. Typically they could receive gifts, own property, elect representatives, enter into contracts, and act as legal persons. Certain religious orders and monasteries developed internal procedures for dispute resolution and ran their own penitential systems. ${ }^{16}$ In seeking to sharpen the boundary between

\footnotetext{
${ }^{12}$ Ulrike Malmendier, "Roman shares," in W illiam N. Goetzmann \& K. Geert Rouwenhorts (eds.), The origins of value: the financial innovations that created modern capital markets 32-40 (Oxford 2005); H. F. Jolowicz \& Barry Nicholas, Historical introduction to the study of Roman law, $3^{\text {rd }}$ ed. (Cambridge 1972), 296-97.

${ }^{13}$ Harold J. Berman, Law and revolution: the formation of the western legal tradition (Cambridge 1983), $215-$ 16. On Justinian's code, generally, see Jolowicz \& Nicholas, Roman law, chaps. 29-30.

${ }^{14}$ Malmendier, "Roman shares," 40.

${ }^{15}$ Kuhn, Law of corporations, pp. 24-29.

${ }^{16}$ Berman, Law and revolution, 69, 89-91, 98, 182, 215-16. The Abbey of Cluny, founded in 910 in Southern France, exercised all of these rights.
} 
themselves and the outside world, some of these early corporations made of point of withdrawing from local politics. ${ }^{17}$

There is a reason why this decentralized incorporation movement gained more visibility in western Europe than in Byzantine territories. In the West states were relatively weak. Charlemagne, who purported to govern vast stretches of western Europe as "emperor" of the Holy Roman Empire (800-14), exercised meaningful authority over only a small area. Most of his ostensible subjects were probably unaware that he ruled over them, if they even knew of him. ${ }^{18}$ Associations thus declared themselves corporations to establish order within their own microcosms and compensate for the absence of a central authority capable of enforcing contracts. The proliferation of self-declared corporations flew in the face, of course, of the principle of regulated incorporation. Without states capable of dictating terms, associations took matters into their own hands, claiming the right of selfgovernance and endeavoring to impose their wills, with varying success, on individuals, groups, and other corporations with whom they interacted.

\section{The Emergence of Formal Corporations}

The centuries of weak state authority in the West coincide with the formative period of Islamic law. Muhammad was born just six years after Justinian's death, and some of Islam's most celebrated early jurists were contemporaries of Charlemagne. Around 1000, as Islamic contract law was assuming the classic form that would remain essentially unchanged for the next millennium, the West was continuing to experiment, in uncoordinated fashion, with the corporate form of organization. A critical step in the development of the corporation was taken about two centuries later. Following the split of Christianity in 1054, and during the struggle to emancipate religion from the control of emperors, kings, and feudal lords (1075-1122), the Roman Catholic Church began calling itself a corporation. This struggle, considered to have culminated in the Papal Revolution, ${ }^{19}$ gave rise to the new canon law (jus novum) of the Catholic Church. Canon law, which dealt with a wide range of

\footnotetext{
${ }^{17}$ There is an unresolved debate on whether the corporations formed in medieval Europe drew on Roman precedents. Otto Gierke, Community in historical perspective (Cambridge 1990), pp. 196-214, 244-45 (orig. ed. 1868), argues that medieval jurists presented the corporation as the revival of an institution found in Roman texts merely for purposes of legitimation. Whatever the practical links between the medieval corporation and Roman law, it is well established that the concept saw use under the Romans.

${ }^{18}$ Walter Ullmann, The Carolingian Renaissance and the idea of kingship: the Birbeck lectures 1968-69 (London 1969), 111-34; S. E. Finer, The history of government, 3 vols., ii (Oxford 1997), 883-88.

${ }^{19}$ Known also as the Gregorian Reform.
} 
issues, including jurisdiction, property, and contracts, built on innumerable concepts, enactments, and rules belonging to the inherited secular and ecclesiastical legal systems. Unlike its forerunners, however, it emerged as a systematized body of law. Articulated in texts, it was supported by theories pertaining to the sources of law. ${ }^{20}$

During the incorporation wave of the sixth through eleventh centuries, all across western Europe the clergy had developed a collective self-consciousness and formed effectively autonomous religious organizations. Now, by claiming a corporate identity of its own, the entire Church sought to differentiate itself from the secular world, separate its assets from those of its members, and weave detached clerical collectives into what has been called a "translocal, transtribal, transfeudal, and transnational" corporation with an autonomously shaped chain of authority. The move would also enhance the power of the Church over clergy by weakening clerical bonds to competing sources of authority, such as the family. Where states regained power, the assertion of legal personhood, too, began to matter. Meanwhile, other attempts were made to form corporations with large memberships and elaborate legal systems. Thousands of towns in northern Italy, France, England, and Germany acquired a corporate identity, in some cases through a royal charter, in others simply through the will of residents and the recognition of outsiders. ${ }^{21}$

Several economic factors fueled the rise of the modern city in western Europe: the revival of commerce, rising agricultural productivity, and migration from the countryside. ${ }^{22}$ These developments made cities larger. Insofar as individuals and other collectivities considered a city a long-lived entity likely to outlast its representatives, it could enter into long-term contracts, borrow at low cost, and threaten punishment credibly. And insofar as it was recognized as autonomous, it could lower its governance costs by making and amending its own bylaws. All of these benefits would have grown with city size. But this cannot be the whole story, for the towns that incorporated in this period varied greatly in population. ${ }^{23}$ Also, similar economic stimuli did not induce an urban

\footnotetext{
${ }^{20}$ Berman, Law and revolution, especially chap. 2; Jolowicz \& Nicholas, Introduction to Roman law, chaps. $16-17$.

${ }^{21}$ Berman, Law and revolution, chap. 12; Henri Pirenne, Medieval cities: their origin and the revival of trade, trans. Frank D. Halsey (Garden City, N.Y. ed. 1956), 121-51 (orig. ed. 1925); Carl Stephenson, Borough and town: a study of urban origins in England (Cambridge, Mass. 1933), especially chaps. 2, 6.

${ }^{22}$ Lewis Mumford, The city in history: its origins, its transformations, and its prospects (New York 1961), 25361; Pirenne, Medieval cities, 55-74, 153-67.

${ }^{23}$ In 1330 more than 3,200 towns dotted the area north of the Alps and the Danube; of these, 94 percent had fewer than 2,000 inhabitants and only nine had more than 25,000 (Norman J. G. Pounds, An historical geography of Europe, 450 B.C.-A.D. 1330 (Cambridge 1973), Table 6.5.
} 
incorporation movement in the Islamic Middle East. The incorporation of western towns must have been facilitated by the broader incorporation movement in the West. The incorporation of charitable and religious associations would have enhanced receptivity to assertions of autonomy and collective identity on the part of towns.

The evolution of the Western corporation depended, then, on the weakening of central authority following the demise of the western Roman Empire. The consequent power vacuum provided incentives as well as opportunities to institute diverse private legal systems as a means of enhancing organizational efficiency. Also critical, however, was a characteristic of Christianity, namely, that it was born in a milieu featuring a strong state. This made it focus on matters of faith, morality, and community, generally ignoring the challenges of economic and political organization. Accordingly, early Christians followed pre-existing legal systems, and usually Roman Law, in their daily interactions, even as they tried to live as good Christians. A precedent was thus set for the coexistence of diverse legal systems, each with its own limited jurisdiction, and with possibly overlapping constituencies. During the incorporation wave that culminated in the Papal Revolution, this precedent facilitated acceptance of a multiplicity of distinct, and in principle independent, legal systems, some religious and others secular.

\section{The Formation of Islamic Law}

During Islam's formative period the peoples of the Middle East, including Muslims, had exposure to the Roman institutional heritage that facilitated incorporation in Europe. Subjects of the early Arab empires, especially Syrians and Egyptians, studied and practiced Roman law, though usually in forms supplemented and modified by local customs. Moreover, converts brought into Islamic discourse legal concepts with which they had familiarity. Islamic law thus borrowed from Roman law directly as well as indirectly, through the region's indigenous communities. ${ }^{24}$

True, relative to their counterparts in western Europe, the corporations established in eastern

\footnotetext{
${ }^{24}$ Patricia Crone, Roman, provincial, and Islamic law: the origins of the Islamic patronate (Cambridge 1987), especially chaps. 1, 5-6. The local forms of Roman law are known collectively as "provincial law." The degree to which Roman law influenced the development of Islamic law is a matter of controversy. Wael B. Hallaq, "The quest for origins or doctrine? Islamic legal studies as colonialist discourse," 2 UCLA J. of Islamic and Near Eastern Law 1-31 (2002-03) proposes that Islamic law grew out of Arabian customs rather than derivatives of Roman law. He acknowledges, however, that those customs were themselves influenced by legal systems of the wider region. In any case, the various influences are not mutually exclusive. Just as students learn from multiple teachers, so in its evolution Islamic law most certainly absorbed elements from multiple legal traditions.
} 
Roman lands tended to enjoy less autonomy. In the Christian East laws governing the internal regulations of monasteries were formulated centrally, and with an eye toward uniformity and discipline. Monasteries were explicitly banned from merging, lest they create large centers of power. ${ }^{25}$ Insofar as early Muslims gained exposure to Roman legal culture through interactions with the inhabitants of Roman or formerly Roman territories, they encountered, then, more than permissive attitudes toward the corporation. They gained familiarity also with the view that the corporation should serve state power rather than decentralized local governance. By the time of the Islamic conquests, it has been observed, municipal institutions of the eastern Roman Empire had declined, and corporate life was more limited in the Roman Middle East than in formerly western Roman territories. ${ }^{26}$ To these factors that help elucidate why Islamic law spurned the concept of a corporation, one may add that in schools that trained Muslims to join the learned class ('ulamā'), Roman law was left out of the curriculum. Even collectively, however, these factors leave much unexplained. During the seventh through tenth centuries, as classical Islamic law was taking shape, any Muslim jurist concerned with organizational efficiency would have known, at a minimum, that the Roman legal tradition offered relevant, if fragmentary, ideas. It is not self-evident, therefore, why the corporation was excluded from the corpus of Islamic law.

One clue lies within the communal organization of pre-Islamic Arabia. At the birth of Islam inhabitants of the Arabian peninsula were divided into tribes bound together by often fictitious blood ties. The individual was expected to support his fellow tribesmen and to assume responsibility for their acts. This system promoted unending feuds. Moreover, intertribal alliances formed for defensive purposes were inherently unstable; routine conflicts triggered escalating violence and a scramble for new alliances. ${ }^{27}$ Because of the resulting insecurity and harm to wealth creation, people stood to gain from an ideology capable of unifying peoples through all-inclusive bonds of

\footnotetext{
${ }^{25}$ Joseph Patrich, Sabas, leader of Palestinian monasticism: a comparative study in eastern monasticism, fourth to seventh centuries (Washington, D.C. 1995), 32-33; Juan María Laboa, The historical atlas of eastern and western Christian monasticism (Collegeville, Minn. 2003), especially chap. 6.

${ }^{26}$ S. M. Stern, "The constitution of the Islamic city," in A. H. Hourani and S. M. Stern (eds.), The Islamic city, 47-48 (Oxford 1970).

${ }^{27}$ This "tribal responsibility system" evokes the "community responsibility system," which, in twelfth- and thirteenth-century Europe, promoted the trust essential to the growth of long-distance commerce (Avner Greif, "Impersonal exchange without impartial law: the community responsibility system," 5 Chicago J. International Law, 109-38 (2004)). As under the latter system, tribes were motivated to keep their members from cheating outsiders, lest the entire group suffer retaliation. Each system generated strategic uncertainty: retaliations could deter cheating or, alternatively, trigger spiraling counter-retaliations and encourage alliance building. The case of pre-Islamic Arabia points to multiple equilibria, implying that a communally-based responsibility system can either benefit or harm growth.
} 
solidarity. ${ }^{28}$

Islam responded to this broad need by promoting communal bonds based on religion rather than descent. "Hold fast, all of you together, to the cable of Allah, and do not separate," says the Qur'an (3:103). “And remember Allah's favor unto you: how you were enemies and ... you became brothers by His grace; and how you were upon the brink of an abyss of fire, and He saved you from it." The community-building referenced in this verse was undoubtedly critical to Islam's rapid diffusion. It fostered an ideology conducive to weakening kinship ties, reducing intertribal violence, and enhancing material security. It also facilitated collective action against outsiders, as evidenced by the early conquests.

Islam's initial emphasis on community building is reflected in the duties enunciated in the Qur'an. Eight of its verses call for "commanding right and forbidding wrong." ${ }^{29}$ Four of these assign this obligation to individuals, the remainder to the collectivity of Muslims (umma).$^{30}$ None imposes the duty on a subgroup of the community, such as an assembly of elders. In fact, the Qur'an says practically nothing on the internal organization of the Muslim brotherhood. Although it does not ban associations formed to pursue legitimate ends, neither does it mention any by name. Accordingly, no collective economic actor appears in the Qur'an, let alone one considered a legal person. Islam's most authoritative source of guidance harbors nothing obvious, then, that might have inspired or supported the corporate form of organization, or justified borrowing it form an outside source.

At the point when the Qur'an became a closed book, tribal bonds remained strong, as evidenced by the prevalence of marriages among kin, the practice of holding people close to the perpetrator of a crime collectively responsible for paying blood money (diyya) to the victim's kin, and the tribal alliances formed in subsequent succession struggles. ${ }^{31}$ Over the next few centuries, as

\footnotetext{
${ }^{28}$ Ignáz Goldziher, Muslim studies, 2 vols., i, S. M. Stern (ed.) (Albany 1967), chap. 2 (orig. ed. 1888); M. A. Shaban, Islamic history: a new interpretation, 2 vols., i (Cambridge 1971), chap. 1.

${ }^{29} 3: 104,3: 110,3: 114,7: 157,9: 71,9: 112,22: 41,31: 17$.

${ }^{30}$ For an exegesis, see Michael Cook, Commanding right and forbidding wrong in Islamic thought (Cambridge 2000), chap. 1.

${ }^{31}$ On the practice of collective responsibility in Islamic criminal law, see Chibli Mallat, "From Islamic to Middle Eastern law: a restatement of the field (part 1)," 51 Am. J. Comp. Law. 702-03 (2003); and Joseph Schacht, "Kisās," Encyclopaedia of Islam, $2^{\text {nd }}$ ed., vol. 5, 177-80 (Leiden 1986). On the early succession struggles, see Patricia Crone, God's rule: government and Islam (New York 2004), chaps. 2-3. Regarding marriage among kin, see Jack Goody, The oriental, the ancient, and the primitive: systems of marriage and the family in the pre-industrial societies of Eurasia (New York 1990), chap. 12; and Gertrude H. Stern, Marriage in early Islam (London 1939), especially 60, 65-66. In recent centuries 10-15 percent of Arab marriages have been among cousins, though the rates have been higher among wealthy groups. See Margaret L. Meriwether, The kin who count: family and society in Ottoman Aleppo, 1770-1840
} 
the medieval Church weakened tribal bonds among Christians through the prohibition of marriage within kin groups, tribalism remained a potent social force among Muslims. ${ }^{32}$ Nevertheless, Islam had unleashed a counter-force that now denied tribalism legitimacy and forced Muslims to cloak nepotism and clannishness in a rhetoric of unity and brotherhood. Though by no means extinguished, tribalism had ceded the high moral ground to a pan-tribal religious ideal.

The Christian injunction to "render to Caesar the things that are Caesar's, and to God the things that are God's" has no analogue in early Islamic discourse. ${ }^{33}$ Muhammad was both a religious and a political leader, and Islamic law was meant to regulate all spheres of life, without ceding ground to secular legislation. On the face of it, the presumed comprehensiveness of Islamic law ruled out self-governance on the part of subcommunities; one could not replace divine law with man-made law even in limited domains. Like the commitment to a union of tribes in one great family, the lack of a formal separation between mosque and state, or the religious and the secular, thus conflicted with the concept of incorporation, and all the more so with the ideal of incorporation at will.

The development of Islamic legal interpretation supported the communal vision embodied in the Qur'an. From the beginning, the interpretation of legal texts was entrusted to trained individuals rather than an organization or office. Acts of a mufti (jurisconsult) were mere opinions. Another mufti could issue a different, yet equally legitimate, opinion. Likewise, a kadi (judge) adjudicated on the basis of his own reading of the law. In principle, his judgments did not create precedents for later judges, not even for later judgments of his own. New cases would be decided through fresh interpretations of the same texts, again by kadis acting as individuals. ${ }^{34}$ In practice, of course, conformist pressures homogenized judicial opinions and decisions. Yet the learned class achieved common positions without the benefit of a hierarchy that could serve as a corporate prototype.

(Austin 1999), 132-40.

${ }^{32}$ Avner Greif, Institutions and the path to the modern economy: lessons from medieval trade (New York 2006), especially 247-55. See also Jack Goody, The European family: an historico-anthropological essay (Oxford 2000), 27-29.

${ }^{33}$ The Biblical teaching is in Matthew 22:21. For detailed comparisons, see Bernard Lewis, Islam and the West (New York 1993), 3-5, 181; and Haroon Khan Sherwani, Studies in Muslim political thought and administration, $4^{\text {th }}$ ed. (Philadelphia 1963), 248, 259-66.

${ }^{34}$ Frank E. Vogel, Islamic law and legal system: studies of Saudi Arabia (Leiden 2000), 14-32; Muhammad Khalil Masud, Brinkley Messick \& David S. Powers, "Muftis, fatwas, and Islamic legal interpretation." in Muhammad Khalid Masud, Brinkley Messick \& David S. Powers (eds.), Islamic legal interpretation: muftis and their fatwas, 3-32 (Cambridge, Mass. 1996); E. Tyan, Histoire de l'organisation judiciaire en pays d'Islam, $2^{\text {nd }}$ ed. (Leiden 1960), chap. 2. 
The tradition of resting legal authority on texts provided rents to individuals with legal training, which they would want preserved. Allowing the formation of self-governing organizations could have diminished those rents by depressing the demand for judgments based on Islamic law. The learned class had reason, therefore, to spurn the concept of a corporation. In western Europe, one might object, literate professions found ways to benefit from the proliferation of corporations. They did so by helping corporations to develop legal systems of their own, thus contributing to the co-existence of multiple jurisprudential traditions, canonistic as well as civilian. ${ }^{35}$ Why would the Middle East's learned class, at least a segment of it, not view corporations in the same light? The difference is that in the West the literate professions were not backed by a centralized state capable of enforcing a unified law. Political power was divided among emperors, kings, and cities, which is why corporations flourished in the first place. In the Middle East the learned class was integrated into centralized states capable of suppressing assertions of self-governance. Moreover, it already enjoyed a monopoly over adjudicating all disputes involving even one Muslim, and played an important role also in the adjudication of lawsuits among non-Muslims. ${ }^{36}$ By encouraging or recognizing incorporation, a kadi would not achieve any obvious economic gain. On the contrary, he would jeopardize his livelihood by raising questions about his loyalty to the state.

Islam's communal vision is reflected in classical Islamic political theory, which matured over several centuries. This largely normative discourse recognizes no political boundaries except that between the abode of Islam ( $d \bar{a} r$ al-Islā $m$ ), consisting of Muslim-ruled territories, and the abode of war ( $d \bar{a} r$ al-harb), governed by non-Muslims. ${ }^{37}$ Tribal loyalties having given way, in theory, to religious brotherhood, the global community of Muslims was to be undivided. ${ }^{38}$ This principle of a unitary community constrained the grouping of individuals for purposes of administration. NonMuslims could be categorized according to their relation to Muslims, as with the distinction between protected "peoples of the book" (ahl al-dhimma) and unprotected foreigners; and either group could be divided further, as necessary. For example, the Venetians could be classified as "friendly" and

\footnotetext{
${ }^{35}$ Walter Ullmann, Law and politics in the Middle Ages: an introduction to the sources of medieval political ideas (Ithaca 1975), chap. 3; Gerald Strauss, Law, resistance, and the state: the opposition to Roman law in Reformation Germany (Princeton 1986), chaps. 1-2.

${ }^{36}$ On the logic of the last observation, see Kuran, "Economic ascent," sects. 5-8.

${ }^{37}$ The distinction is customarily based on Qur'an 47:4.

${ }^{38}$ Ahmad S. Dallal, "Ummah," Oxford encyclopedia of the Islamic world, vol. 4 (New York 1995), 267-70 ;
} Ann K. S. Lambton, State and government in medieval Islam (Oxford 1981), 13-14. 
accorded rights denied to Spaniards. By contrast, all Muslims, at least those of similar social status, had to have essentially equal political and economic rights, regardless of ancestry, language, or place of residence.

There existed, of course, practices in conflict with this broad ideal. Precisely because ancestry remained a source of legitimacy, many rulers claimed descent from Muhammad. The extension of inheritance rights beyond the nuclear family, to secondary relatives, strengthened kinship ties, as did sharp limits on testamentary freedoms. Yet, the ideal was not honored only in the breach. Up to modern times trade tariffs distinguished in the first instance between Muslims and non-Muslims. Whereas the latter could pay duties at various rates, a single rate applied to all Muslims, including the subjects of unfriendly Muslim rulers. In spite of a long history of Turkish-Iranian rivalry, the Ottoman and Safavid Empires charged each other's Muslim subjects the same duties that they charged their own. The procedures of pre-modern Islamic courts offer a second example. Whereas a Greek or Armenian would be identified as such, a Muslim Arab, Turk, or Albanian would be identified simply as a Muslim, often implicitly. Partly as a consequence, national self-awareness developed more slowly among Muslims than among non-Muslims. ${ }^{39}$

There were several reasons, then, for Islam's early promoters to spurn a concept liable to facilitate factionalism. Most critically, they were afraid of stoking the embers of tribalism, and their states were capable of blocking institutions liable to stimulate rival forms of solidarity. It does not follow, of course, that the life of the community would remain free of characteristics we now associate with the corporation. A form of legal personhood emerged in the above-mentioned practice of collective punishment for murder. The same is true of the practice, used by various Muslim rulers from an early period, of collective responsibility for taxation. ${ }^{40}$ A measure of self-governance appeared in the legal autonomy granted to Jews and Christians on civil matters, although the supremacy of Islamic law, and the right of anyone to ask unilaterally to be judged by an Islamic court, limited the collective powers of minority communities. ${ }^{41}$ For yet another example, both limited liability and the separation of ownership from control were inherent in mudaraba, the most common

\footnotetext{
${ }^{39}$ Hasan Kayal1, Arabs and Young Turks: Ottomanism, Arabism, and Islamism in the Ottoman Empire, 19081918 (Berkeley 1997); Rashid Khalidi, Lisa Anderson, Muhammad Muslih \& Reeva S. Simon (eds.), The origins of Arab nationalism (New York 1991); Justin McCarthy, The Ottoman peoples and the end of empire (New York 2001).

${ }^{40}$ Claude Cahen, "Darība," Encyclopaedia of Islam, $2^{\text {nd }}$ ed., vol. 2 (Leiden 1965), 143-44; Claude Cahen, "Kharādj, in the central and western Islamic lands" Encyclopaedia of Islam, $2^{\text {nd }}$ ed., vol. 4 (Leiden 1978), 1030-34.

${ }^{41}$ On the logic of how Islamic legal pluralism undermined its own ostensible objectives, see Kuran, "Economic ascent," especially sects. 8-9.
} 
form of Islamic partnership. From such elements, examined in greater detail below, any wellmotivated legal scholar could have derived the corporation. Absent that motivation, these elements did not even emerge as abstract legal concepts.

\section{Emergence of the Waqf}

Early Muslims, including the learned class, were motivated to develop some organization capable of indefinite existence. If nothing else, the huge start-up costs of providing certain durable social services created a need, as it did elsewhere, for an organizational form able to spread those costs over a long horizon. Mosques, fountains, and schools offer examples of structures that are both expensive to build and have an extended economically useful life. One possible organizational solution is the corporation. By virtue of its perpetuity, an incorporated town may build a fountain and then manage it indefinitely on behalf of its residents. That solution was adopted widely in western Europe.

But there existed alternatives. In the Islamic Middle East a wide variety of services, including ones with high start-up costs, came to be provided by the waqf, a type of unincorporated trust. At one level, this institutional choice was stunningly successful. In the Middle Ages waqfs contributed critically to the functioning of cities far larger than any town in the West; without direct state involvement, they financed the building and maintenance of innumerable urban services. In the famous account of his journeys through the Islamic world, Ibn Battuta (1304-69) speaks of a dazzling variety of waqfs, including ones dedicated to providing drinking water, the paving of streets, assistance to travelers, the financing of pilgrimages, and wedding outfits to impoverished brides. ${ }^{42}$ Outside of cities, most of the caravanserai (fortified inns) used by traveling merchants were funded by a waqf. ${ }^{43}$ In Marshall Hodgson's words, the waqf served as a "vehicle for financing Islam as a society." $" 4$

A waqf was established by an individual owner of immovable property to supply in

\footnotetext{
${ }^{42}$ Ibn Battuta, The Travels of Ibn Battūta (A.D. 1325-1354), 2 vols., ed. H. A. R. Gibb (Cambridge 1958-62), especially i, 64-65, 148-49 and ii, 450 .

${ }^{43}$ See Kuran, "The provision of public goods under Islamic law: origins, impact, and limitations," 35 Law \& Soc. Rev. 841-97 (2001); Bahaeddin Yediy1ldız, "Müessese-toplum münâsebetleri çerçevesinde XVIII. asır Türk toplumu ve vakıf müessesesi," 15 Vakıflar Dergisi 23-53 (1982); Murat Çizakça, A history of philanthropic foundations: the Islamic world from the seventh century to the present (Istanbul 2000); and Said Amir Arjomand, "Philanthropy, the law, and public policy in the Islamic world before the modern era," in W. F. Ilchman, S. N. Katz \& E. L. Queen (eds.), Philanthropy in the world's traditions, 109-32 (Bloomington 1998).

${ }^{44}$ Marshall G. S. Hodgson, The venture of Islam: conscience and history in a world civilization, 3 vols., ii (Chicago 1974), 124.
} 
perpetuity any function deemed legitimate under Islamic law, except for state-monopolized functions, such as warfare. Like a corporation, it could be fine-tuned to specific needs. It shared with the corporation also the capacity to outlive its founder, employees, and beneficiaries. ${ }^{45}$ But there were also major differences. First, whereas an association could turn itself into a corporation through the collective will of its members, ordinarily the founder of a waqf had to be an individual. ${ }^{46}$ Second, whereas a corporation was meant to be controlled by a changing membership, a waqf was supposed to be controlled forever by its founder, through directions enunciated in the founding deed (waqfiyya). Accordingly, a waqf's mission was irrevocable; not even its founder was authorized to alter its declared purpose retroactively. A third difference concerned self-governance. Unlike a corporation, which could remake its own rules, a waqf's rules of operation were meant to be fixed; the founder's instructions were enforced through judges and, where the deed was silent, according to local custom.

Just as the Church did not invent its corporate identity from scratch, so the waqf did not emerge in an institutional vacuum. The concept of a trust was present in Roman law; and pre-Islamic peoples of the Middle East used it in various forms. ${ }^{47}$ Why, then, would early Muslims have found the concept of trust congenial, even as they spurned the corporation? Although no evidence exists a deliberate choice, the selection of the waqf accords with Islam's communal vision, discussed above. Insofar as Muslim leaders considered factionalism a threat, they would have favored an institution established and directed by an individual to one involving self-governance by an organized group.

To identify a reason why rulers would approve of the waqf and oppose the corporation does not explain, of course, why individuals would want to found them. Two common motives were generosity and prestige. Even jointly, however, these motives could not have accounted for the range of services supplied. Another, often the major, inducement for endowing a waqf is that it provided pecuniary gains to the founder and his family. The founder could appoint himself the waqf's mutawalli (manager-trustee), set his own salary, hire relatives to paid positions, and even designate

\footnotetext{
${ }^{45}$ Kuran, "Provision of public goods," 841-52; Çizakça, Philanthropic foundations, 15-21.

${ }^{46}$ The collective waqf of guilds, discussed further on, forms an exception.

${ }^{47}$ Peter C. Hennigan, The birth of a legal institution: the formation of the waqf in third-century A.H. Hanafi legal discourse (Leiden 2004), 50-70; Fuad Köprülü, "Vakıf müessesesinin hukukî mahiyeti ve tarihî tekâmülü," 11 Vak1flar Dergisi 3-5 (1942); David S. Powers, "The Islamic family endowment (waqf)," 32 Vanderbilt J. of Transnational Law 1171-72 (1999); William R. Jones, "Pious endowments in medieval Christianity and Islam," 109 Diogenes 23-26 (1980).
} 
his successor, thus bypassing Islam's inheritance regulations. In endowing assets as waqf a founder also made them more secure. Rulers prone to expropriate in times of distress were less likely to confiscate waqf assets than private property. Hence, the waqf served as a wealth shelter. The credibility of this insurance depended on the waqf's presumed sacredness, based partly on its absorption into Islamic law and partly on the attention paid in public discourse to the piety motive of founders. The belief that property becomes sacred upon being endowed as waqf is what discouraged the confiscation of waqf property, for rulers had much to lose by appearing impious.

Just as the founder of a waqf sought a credible commitment to the security of his endowment, so a ruler who gave up opportunities to expropriate sought to have the founder commit credibly to supplying his chosen social services. Constraining the mutawalli to follow the waqf deed to the letter was an attempt to ensure that commitment. Put differently, waqfs were designed as inflexible in order to mitigate the agency problem inherent in delegating implementation of the founder's instructions to successive individuals liable to divert assets to their own uses.

The "static perpetuity" principle of the waqf emerged, then, as part of an implicit social bargain between rulers and the owners of private property. That the bargain could result in inefficiencies must have been understood, for escape valves were instituted to enable pressing changes. But the flexibility was strictly limited. In some places and times the standard formulary for establishing a waqf contained a list of allowable operational modifications. ${ }^{48}$ However, only one set of changes could be made; once the right was exercised, static perpetuity would apply forevermore. Sooner or later, therefore, the judgments and preferences of mutawallis, employees, and intended beneficiaries would cease to matter; in principle, both the waqf's mission and its mode of operation would become frozen. What if there came a point when the mission could no longer be met, as when changing trade routes made a waqf-financed caravanserai fall into disuse? Under such circumstances could this waqf's mission be redefined? As the law was commonly understood, the mutawalli lacked the necessary authority. If the caravanserai were abandoned, by default its supporting assets would accrue to the poor. Yet another manifestation of static perpetuity is that two or more established waqfs could not pool their resources to benefit, say, from economies of scale.

The establishment of a waqf was construed as the withdrawal from circulation of its corpus

\footnotetext{
${ }^{48}$ Ahmet Akgündüz, İslam hukukunda ve Osmanl1 tatbikat1nda vak1f müessesesi, $2^{\text {nd }}$ ed. (Istanbul 1996), 257 70; Donald P. Little, A catalogue of Islamic documents from al-Haram al Sarif in Jerusalem (Beirut 1984), 317-18.
} 
and the assignment of its revenue to the designated service. ${ }^{49}$ Understandably, the service had to be commensurate with the expected revenue. A major endowment was needed to finance the construction and maintenance of a congregational mosque; in the event of a perceived mismatch between projected rental income and expected expenditures, the courts might disallow the waqf. Against this background, static perpetuity seems to have been designed also to safeguard its capacity to meet its social obligations.

Whatever the motives underlying the waqf's characteristic features, they produced unmistakable inefficiencies. These are visible in contrasting the colleges established in the Middle East as waqf-financed madrasas with those founded contemporaneously in the West as universities. The early universities of Europe, such as Paris (1180) and Oxford (1249), were founded as trusts resembling the waqf. ${ }^{50}$ But they quickly became self-governing and self-renewing organizations through incorporation. By contrast, madrasas continued to be constrained by the directives of their founders. Over time, therefore, the curriculum changed less in madrasas than in universities, helping to turn the Middle East into an intellectual backwater. ${ }^{51}$ Although many factors contributed to the Middle East's lack of intellectual prominence after several bright centuries under Islamic rule, a basic cause lies in the waqf's organizational limitations.

Madrasas and universities were both non-profit organizations. Their differences late in the second millennium may be traced to a fateful divergence of paths initiated soon after the birth of Islam. As Figure 1 shows, the waqf became Islam's main organizational form for providing social services at a time when western Europe started to use the corporation to many of the same ends. The organizational gap widened further at the end of the sixteenth century, when the West began applying the corporate form of organization to profit-oriented production, finance, and commerce.

\footnotetext{
${ }^{49}$ Joseph Schacht, An introduction to Islamic law (Oxford 1964), 125-26.

${ }^{50}$ There is evidence that waqf law and the structure of the madrasa influenced the initial organization of the university [Monica M. Gaudiosi, "The influence of the Islamic law of waqf on the development of the trust in England: the case of Merton College," 136 University of Pennsylvania L. Rev. 1231-61 (1988)] . However, the university quickly metamorphosed into a very different organization. Unlike the madrasa, the mature university enjoyed legal personhood. Where a university granted degrees as an organization, successful madrasa students received certificates of competency ( $i j \bar{a} z a)$ from individual teachers. See George Makdisi, The rise of colleges: institutions oflearning in Islam and the West (Edinburgh 1981), 140-52.

${ }^{51}$ Makdisi, Rise of colleges; Toby E. Huff, The rise of early modern science: Islam, China, and the West, $2^{\text {nd }}$ ed. (Cambridge 2003), chap. 5; Pervez Hoodbhoy, Islam and science: religious orthodoxy and the battle for rationality (London 1991). For stark comparative statistics relating to the modern era, see United Nations Development Programme, Arab human development report 2003: building a knowledge society (New York 2003), chap. 3.
} 


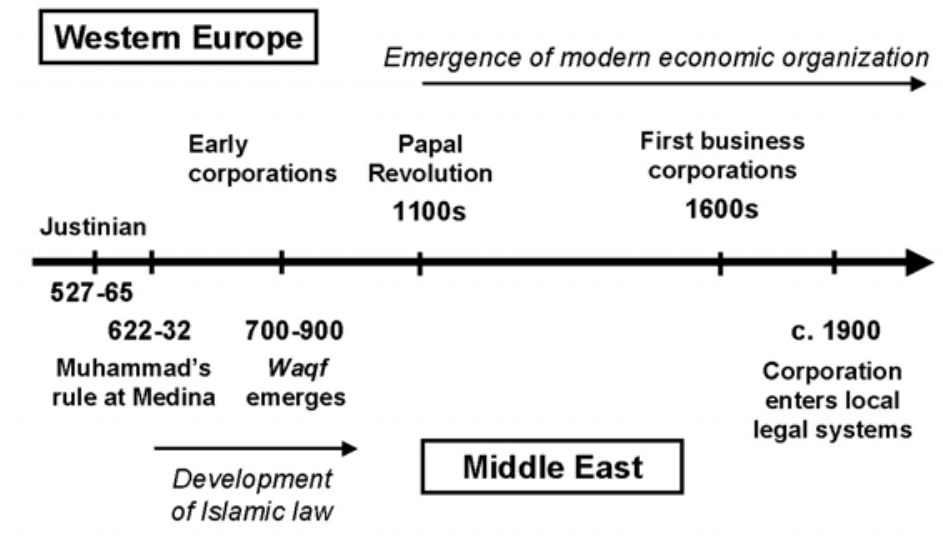

Figure 1. Organizational divergence: The Middle East and western Europe.

\section{Precursors of the Business Corporation}

Given the stimulus that commercial revival gave to the incorporation movement in medieval Europe, it is unsurprising that merchants contributed to the legal transformation. The late eleventh and twelfth centuries saw the emergence of mercantile law (lex mercatoria or "law merchant") over large areas, partly through the systematization of Roman rules. ${ }^{52}$ Although the boundaries among certain jurisdictions (for example, the frontier between mercantile law and canon law) remained controversial, on many matters the supremacy of mercantile law attained almost universal acceptance. The adjudication of commercial disagreements was generally left to commercial courts composed of judges elected by merchants. ${ }^{53}$

Not until the late sixteenth century did commercial enterprises start getting organized as corporations. As the next section will show, the impetus was the global discoveries and consequent invigoration of overseas trade. The expansion of trade relied on capital outlays for periods unusually long by historical standards and from growing numbers of investors. However, organizational

${ }^{52}$ Berman, Law and revolution, chap. 11.

${ }^{53}$ As early as 1154, northern Italy had commercial courts consisting of merchant judges (consules mercatorum). See W. Mitchell, An essay on the early history of the law merchant (Cambridge 1904), chap. 3; and Paul Milgrom, Douglass North \& Barry Weingast, "The role of institutions in the revival of trade: the medieval law merchant," 2 Economics and Politics 1-23 (1990). 
features now associated with the business corporation, and practices essential to its workings, had already emerged over the preceding three centuries.

Prior to the thirteenth century, a leading form of resource pooling among European merchants was the commenda, which dissolved at the exit or death of any partner. This dissolution provision restricted the scale and horizon of profit-making enterprises. ${ }^{54}$ The Italians sought to overcome the limitation through the "family firm" (compagnia) - a partnership formed mostly by kin, with each partner assuming unlimited and joint liability. Although a family firm would get liquidated at the death of a partner, it would immediately be reconstituted, usually retaining the name as well as the capital. The largest family firms accumulated assets comparable to those of rulers. ${ }^{55}$ Critical to the success of the family firm is that its longevity and liability provisions imparted credibility to its contractual promises. Also critical is that cities had the power to enforce the obligations of local firms and, because a default by one firm would cast doubt on the commitments of others, also a motivation to do so. ${ }^{56}$ The family firm's lasting contribution to organizational development lies in its demonstration of the value of large and durable enterprises. Yet its reliance on kinship bonds limited its applicability. So did its liability rules, which denied both owner shielding and entity shielding. Liability rules acceptable within a tight-knit family created intolerable risks across family boundaries. Understandably, people were reluctant to invest in an enterprise comprising strangers who might encumber them, or the enterprise itself, with unplanned obligations.

Another Italian innovation was the hub-and-spoke system devised to coordinate legally independent partnerships. The famous Medici firm (1397-1494) consisted of a controlling partnership (the hub) and numerous subsidiary partnerships (spokes), each with a branch manager who assumed joint and unlimited liability for debts of his own branch. In principle, that branch manager was liable also for the debts of other branches. However, because each partnership kept separate books, and because of transportation and communication costs, the creditors of each branch office had first claim on its assets. Hence, as a practical matter creditors treated the Medici partnerships as independent, which limited the liabilities of any one branch. Such partitioning of

\footnotetext{
${ }^{54}$ Kuran, "Islamic commercial crisis," 417-18, 421-22.

${ }^{55}$ The Bardi firm accumulated assets 4.5 times greater than those of the English king. See Avner Greif, "The study of organizations and evolving organizational forms through history: reflections from the late Medieval family firm," 5 Industrial and Corporate Change 476-77 (1996); and Edwin S. Hunt, The medieval super-companies: a study of the Peruzzi company of Florence (Cambridge 1994), especially chaps. 1-2.

${ }^{56}$ Greif, "Evolving organizational forms," 489-90.
} 
assets, in providing a measure of owner shielding, promoted investment in the overall enterprise. This is because investors needed to trust only the controlling parties; the trustworthiness of the manager in Bruges was of limited relevance to an investor in Pisa. ${ }^{57}$ The structural complexity of the full Medici enterprise also stimulated the development of double-entry bookkeeping, as a means to depersonalize accounting and make records transparent and comparable. ${ }^{58}$ Two centuries later, these advances in accounting would facilitate the spread of the business corporation by enabling shareholders to monitor its financial flows.

The Medici enterprise lasted 97 years - by medieval standards, an eternity. Another Italian attempt at greater longevity involved the posting of resident partners in distant lands. Instead of returning home at the conclusion of a contracted trading mission, a resident partner would send a share of accumulated capital to his inactive partners at home as a dividend, receive authorization to reinvest the remainder, repatriate some profits again, and so on indefinitely. Through serial commenda these spatially separated partners thus acquired a lasting commercial identity. The arrangement presaged a key characteristic of the business corporation: durability. ${ }^{59}$ A durable enterprise can make long-term commitments more credibly than one vulnerable to early termination.

Another salient feature of the business corporation is the tradability of shares. By the fourteenth century the Italian maritime partnership (societas navalis) involved a ship as capital, divided into shares (carati). A shareholder's liability was limited to his own interest in the ship. His shares were tradable, though often the permission of other shareholders was required. ${ }^{60}$ The provision was intended to keep managerial control from falling to unapproved people. This organizational innovation augmented the scale of resource pooling. Maritime partnerships usually involved 5 to 24 shares, with as many investors.

Yet another precursor of the business corporation is the Genoese Bank of San Giorgio,

\footnotetext{
${ }^{57}$ Raymond De Roover, The rise and decline of the Medici Bank, 1397-1494 (Cambridge, Mass. 1963), chap. 5; Greif, "Evolving organizational forms," 494-97; Hansmann, Kraakman \& Squire, "Rise of the firm," in press.

${ }^{58}$ Raymond De Roover, Business, banking, and economic thought in late Medieval and early modern Europe, ed. Julius Kirshner (Chicago 1974), chap. 3; Hunt, Medieval super-companies, chap. 4. For earlier advances in accounting, see Geoffrey Alan Lee, “The development of Italian bookkeeping, 1211-1300," 9 Abacus 137-55 (1973).

${ }^{59}$ Before the law, the partnership was treated as temporary. In 1271 Venetian authorities drove home the point by limiting the duration of a partnership to two years and banning the practice of sending profits and receiving capital without a personal appearance. From their standpoint, the problem is that reducing the frequency of capital repatriation limited tax revenue. See Benjamin Z. Kedar, Merchants in crisis: Genoese and Venetian men of affairs and the fourteenth-century depression (New Haven 1976) 25-26.

${ }^{60}$ Murat Çizakça, A comparative evolution of business partnerships: the Islamic world and Europe, with special reference to the Ottoman archives (Leiden 1996) 27-32.
} 
founded in 1407. The shareholders of this chartered bank received dividends tied to profits. Management was controlled by the largest shareholders; the smallest did not even vote in the general assembly. ${ }^{61}$ This arrangement represented a step toward the separation of management from ownership, a basic characteristic of the business corporation. In a simple partnership any member, through his power to force liquidation, can veto any decision. In concentrating authority in large shareholders, certain enterprises of fourteenth- and fifteenth-century Italy deprived lesser members of unilateral power. Hence, these enterprises could grow without sacrificing governability. Insofar as their shares were tradable, they also enjoyed greater longevity than a simple partnership.

The foregoing organizational features and techniques - tradability of shares, separation of ownership from management, double-entry bookkeeping, owner shielding—spread slowly among profit-making enterprises. ${ }^{62}$ Nevertheless, in the middle of the second millennium, when corporations were being founded for political, educational, civic, and religious purposes, they began to demonstrate how features destined to become united in the business corporation could benefit production, finance, and commerce. They also broadened the options of ambitious but risk-averse investors and merchants.

Shortly we shall explore why analogous organizational dynamism was lacking in the contemporaneous Middle East. The issue is not, of course, why any particular development - the Medici conglomerate, the Bank of San Giorgio - was not replicated. No single development proved indispensable to the subsequent emergence of the business corporation. Each represented one of many uncoordinated attempts to accumulate capital and gain longevity while protecting joint assets, limiting risks, and achieving transparency. Two aspects of the European record are particularly significant. One is the dynamism itself, and the other that the engine of the dynamism consisted of multitudes of private agents, generally acting independently. Indeed, diverse initiatives came from private businessmen; although states facilitated certain arrangements, they did not direct them. Against this background, it is telling that Abdülmecit established his organizational prototype from above, as an initiative of the Ottoman administration. He took the lead precisely because

\footnotetext{
${ }^{61}$ Steven A. Epstein, Genoa and the Genoese, 958-1528 (Chapel Hill 1996) 260-61, 277-81, 304-6; Kuhn, Law of corporations, 34-38.

${ }^{62}$ For more on these advances, see Jonathan Barron Baskin \& Paul J. Miranti, Jr., A history of corporate finance (Cambridge 1997), chap. 2; Edwin S. Hunt \& James M. Murray, A history of business in medieval Europe, 1200-1550 (Cambridge 1999), especially chaps. 6-10; Ann M. Carlos \& Stephen Nicholas, "Giants of an earlier capitalism: the early chartered companies as an analogue of the modern multinational," 26 Bus. Hist. Rev. 398-419 (1988); and Greif, "Evolving organizational forms."
} 
organizational modernization had not come from below, through innovations of producers, merchants, financiers, and investors themselves.

\section{Overseas Trading Companies and the Maturing of the Business Corporation}

For all their contributions to organizational modernization, the Italians stopped short of applying the long-available corporate concept to profit-making enterprises. It is the English and Dutch who, in the late sixteenth century, and more saliently in the following century, developed the earliest business corporations. The stimulus was the opening up of new trading opportunities through global explorations. Incorporated overseas trading companies emerged as part of a drive to corner markets on behalf of particular groups of merchants. Their evolution entailed three patterns of interest here. First, an advance could occur through multiple paths. Second, organizational innovations were induced, as before, by identifiable economic goals, such as entity shielding and reduced governance costs. Finally, organizational innovations often generated unintended problems, which triggered further innovations, making creativity feed on itself.

The overseas trading companies included the Levant Company, formed by English traders active in the Middle East, and the East India Companies of the Dutch and English, which conducted business in a region governed partly by Muslims and visited by Middle Eastern traders. Each company followed a distinct evolutionary path in adopting key features of the modern firm: capital maintained in perpetuity, impediments to free riding on the part of the beneficiaries of companyprovided public goods, transferability of shares, professional management, separation of ownership and control, restrictions on encumbering the firm, and legal personhood.

The key challenge of each company was to raise abundant fixed and working capital. This objective produced a deal between three sets of players: active participants in the company's business, investors who would passively await returns, and the state, which provided the company a charter and helped to enforce agreements among its members. The state's involvement was immediate in England, where the lack of a legal tradition of owner shielding required incorporation from the start. It came at a later stage in Holland, where enterprises formed as commenda took to coordinating activities within a single company. ${ }^{63}$ Whatever the exact pattern, the state shared in the resulting profits through taxes and cheap loans. It also benefitted from certain company assets:

\footnotetext{
${ }^{63}$ Ron Harris, "The formation of the East India Company as a cooperation-enhancing institution" (December 2005), available at the Social Science Research Network: http://ssrn.com/abstract $=874406$.
} 
embassies, consulates, trade facilities, and ships deployable in warfare. ${ }^{64}$

Both the English and the Dutch companies stimulated the development of secondary markets for shares, though the circumstances differed. English companies were chartered as regulated enterprises whose members traded on their own account, rather than for the collectivity. Membership could not be obtained merely by purchasing a share; an apprenticeship was required. Moreover, although shares were transferable, other members had to consent. These enterprises provided public goods to their members, including rules in their collective interest. ${ }^{65}$ The public goods enhanced share prices, as did the availability of opportunities to liquidate shares through a growing secondary market. Constituencies thus emerged for relaxing restrictions on transferability, and the existing companies evolved into joint-stock companies. Interest in a joint-stock company could be transferred at will. This evolution was instrumental in the growth of individual companies. Established by 20 merchants in 1581, the Levant Company had 87 members in 1600, and 200 a century later. ${ }^{66}$ To turn to the Dutch case, at its establishment in 1602 the Dutch East India Company's charter was to last until 1612, when its assets would be distributed to shareholders. Eager to protect its ships, the company invested in forts along the African coast. Alas, at the end of the ten-year period, the forts could not be liquidated. With shareholders demanding returns, the Dutch parliament renewed the company's charter, though as a joint-stock company. Thenceforth, the company was to have a perpetual existence, and partners could exit simply by selling their shares.$^{67}$ Driven by liquidity needs, these innovations stimulated the development of local stock markets. From different starting

\footnotetext{
${ }^{64}$ Because of its stake in the chartered company's profitability, the state sometimes supervised the appointment of its managers and apportionment of its dividends. If a rent failed to materialize, or was disappointingly low, the state might revoke a charter. In 1600, when an unchartered group of merchants promised to pay higher taxes in return for the Levant Company's privileges, the Queen of England revoked the Levant charter, restoring it only in return for higher annual contributions [Alfred C. Wood, A history of the Levant Company (London 1935) 36]. See, generally, Ekelund \& Tollison, Politicized economies, especially chap. 6; Harris, Industrializing English law, chap. 2; Wood, Levant Company, chaps. 1-7; Robert Brenner, Merchants and revolution: commercial change, political conflict, and London's overseas traders, 1550-1653 (Princeton 1993), especially chaps. 1, 12; and John P. Davis, Corporations: a study of the origin and development of great business combinations and their relation to the authority of the state, 2 vols. (New York 1961)(orig. ed. 1905).

${ }^{65}$ Harris, Industrializing English law, 32, 146-47; Kuhn, Law of corporations, 46-48.

${ }^{66}$ Wood, Levant Company, 23-24, 151. Not all members were engaged in trade; some were passive investors.

${ }^{67}$ Leonard Blussé \& Femme Gaastra, "Companies and trade: some reflections on a workshop and a concept," in Leonard Blussé \& Femme Gaastra (ed.), Companies and trade 8 (Leiden 1981); Larry Neal, "Venture shares of the Dutch East India Company," in William N. Goetzmann \& K. Geert Rouwenhorts (eds.), The origins of value: the financial innovations that created modern capital markets 166-71 (Oxford 2005); Albert Hyma, The Dutch in the Far East: a history of the Dutch commercial and colonial empire (Ann Arbor 1942), chap. 2; Jan De Vries, Economy of Europe in an age of crisis, 1600-1750 (Cambridge 1976), 128-46.
} 
points, then, both England and Holland established one of the prerequisites of a profit-making corporate sector.

The history of the overseas companies also shows how efforts to solve problems stemming from novel institutions triggered new innovations, giving the organizational transformation a momentum of its own. Initially, the members of an English company pooled resources for a specific commercial voyage, as they might under a commenda. Thus, a share of the Levant Company entitled its bearer to a portion of the returns from a specific voyage to the Middle East. If merchant $i$ held shares in a voyage beginning in March 1602, and merchant $j$ in one starting in June 1602, as a matter of principle their returns were mutually independent. However, because goods from separate voyages were often stored and marketed jointly, allocating profits sowed mistrust. The response was to issue terminable stock that provided a claim on all returns earned during a designated period. This arrangement had a drawback of its own: misalignment between income streams and liquidity needs. The next logical step was the issuance of permanent stock, which provided returns over an indefinite period, until it passed to a new owner. ${ }^{68}$ In today's business corporations, this is the typical pattern.

Simple organizational forms would remain popular. The incorporation option was of little structural consequence to small businesses, often organized as sole proprietorships, family enterprises, or simple partnerships, as in the past. Joint-stock companies, including incorporated ones, achieved prevalence only in the early eighteenth century; by 1717 they held 5.2 percent of England's national wealth, up from 0.013 percent in $1560 .{ }^{69}$ In 1760 , according to another estimate, the total capital of joint-stock companies amounted to 15 percent of England's net reproducible capital stock, and by 1840 this figure stood at 24.5 percent. ${ }^{70}$ Nevertheless, the reviewed experiences of the period before the eighteenth century provided the institutional fine-tuning and know-how to deploy the business corporation widely, if ever this became optimal. As the Industrial Revolution unfolded, the corporate form proved useful especially in sectors where efficiency required hundreds, if not thousands, of workers to use extensive capital in coordinated fashion. It gave a further stimulus

\footnotetext{
${ }^{68}$ Ekelund \& Tollison, Politicized economies, 190-91. Kuhn, Law of corporations, 48-50; Niels Steensgaard, "The companies as a specific institution in the history of European expansion," in Leonard Blussé \& Femme Gaastra (eds.), Companies and trade, 246-51 (Leiden 1981); William Robert Scott, The constitution and finance of English, Scottish and Irish joint-stock companies to 1720, 3 vols., ii (Cambridge 1910-12), 97-98; Baskin \& Miranti, History of corporate finance, chap. 2.

${ }^{69} \mathrm{Scott}$, Joint-stock companies to 1720, i, 439. The figure includes land owned by joint-stock companies. As a result of the financial bubble generated by the South Sea Company, the share rose to 13 percent in 1720 .

${ }^{70}$ Harris, Industrializing English law, 193-98.
} 
to the mobilization of capital through measures to shield corporate assets from individual shareholders and their creditors. In encouraging the appropriation of corporate earnings, as opposed to raiding corporate assets, it also reduced shareholder risks. ${ }^{71}$ Although other organizational forms, including various types of unincorporated joint-stock companies, remained in use, the business corporation thus contributed to the financing and management of industrial capitalism. ${ }^{72}$

The development of the business corporation would continue, as would that of the requisite law. ${ }^{73}$ A key development of the nineteenth century was "free incorporation"- the right to incorporate at will, without the consent of a monarch, president, or parliament. ${ }^{74}$ Meanwhile incorporation itself gained flexibility; for example, it became routine to modify voting rules to suit special needs. Because the Middle East ultimately borrowed the French commercial code, it is worth noting that at the founding of Şirket-i Hayriye incorporation remained restrictive in France. However, the advantages of incorporation were replicated by corporate-like French partnerships endowed with legal personhood. Also, French law treated entity shielding and owner shielding as continuous variables, not, as in the Anglo-American tradition, as dichotomous choices. Partnership contracts included clauses that restricted partner liabilities and identified who could encumber the firm. There could be supervisory committees and reporting requirements. Furthermore, partnerships could be organized with tradable shares (commandites par action). In short, French merchants and financiers could obtain most advantages of incorporation through registered and finely-tuned partnerships. $^{75}$

\footnotetext{
${ }^{71}$ Hansmann, Kraakman \& Squire, "Rise of the firm," in press.

${ }^{72}$ Harris, Industrializing English law, 282-85; Naomi R. Lamoreaux, "Partnerships, corporations, and the limits on contractual freedom in U.S. history: an essay in economics, law, and culture," in Kenneth Lipartito \& David B. Sicilia,Constructing corporate boundaries: history, politics, culture, 29-65 (New York 2004).

${ }^{73}$ See William G. Roy, Socializing capital: the rise of the large industrial corporation in America (Princeton 1997), especially chaps. 6-9; Alfred D. Chandler, Jr., The visible hand: the managerial revolution in American business (Cambridge, Mass. 1977), especially chaps. 12-14; Lamoreaux, "Partnerships, corporations"; and Oliver E. Williamson, The economic institutions of capitalism: firms, markets, relational contracting (New York 1985), especially chaps. 11 12.

${ }^{74}$ In England, where the corporation came to dominate business organization in the mid-nineteenth century, not until 1844 could corporations be formed without explicit state permission. The chartering process led to extensive rent seeking, partly on the part of incumbent corporations seeking to limit the organizational capabilities of their rivals. See Harris, Industrializing English law, 282-85. On general incorporation acts in the United States, see John Joseph Wallis, "Constitutions, corporations, and corruption: American states and constitutional change, 1842 to 1852 ," 65 Journal of Economic History 211-256 (2005).

${ }^{75}$ Naomi R. Lamoreaux \& Jean-Laurent Rosenthal, "Legal regime and contractual flexibility: a comparison of business's organizational choices in France and the United States during the era of industrialization," 7 Am. Law and Econ. Rev. 37-42 (2005).
} 
Nothing here presupposes that as an organizational form the corporation is necessarily superior to the partnership, regardless of circumstances. Although many analysts treat the corporation as relatively efficient, in fact, both forms of organization have advantages and disadvantages that present tradeoffs. Whereas in a growing partnership decision making becomes cumbersome, in a numerically equivalent corporation managerial control, rather than decision making, poses the greater challenge. That is why in industrial economies the incidence of partnerships and corporations has varied by sectors and over time, to match differing tradeoffs. ${ }^{76}$ What is undeniable is that the unprecedented prosperity of the modern age, like the economic leadership of the West, has depended on a movement toward larger, more complex, and more durable profit-seeking enterprises. ${ }^{77}$ And this has required advanced organizational forms. In nineteenth-century France, partnerships remained the most common organizational form, but the larger the enterprise, as measured by either employment or capital, the more likely it was to have corporate-like features and to be an outright corporation. ${ }^{78}$ By the same token, the increase in organizational scale, complexity, and longevity was accompanied by a rise in the use of advanced financial techniques, such as double-entry bookkeeping and the trading of equity. ${ }^{79}$

\section{Missed Middle Eastern Opportunities}

The enormous advantages of the corporation bring us back to the stagnation of business organization

\footnotetext{
${ }^{76}$ For examples of analyses that take the superiority of the corporation for granted, see Williamson, Economic institutions of capitalism, chaps. 11-12; Margaret M. Blair, "The neglected benefits of the corporate form: entity status and the separation of asset ownership from control," in Anna Gandori (ed.), Corporate governance and firm organization: microfoundations and structural forms, 45-66 (New York 2004); and Jean Tirole, "Corporate governance,"69 Econometrica 1-35 (2001); Naomi R. Lamoreaux and Jean-Laurent Rosenthal, "Organizing middle-sized firms in the United States and France, 1830-2000," UCLA working paper, September 2005, model the tradeoffs faced in choosing an organizational form.

77 The history of the business corporation is not unblemished. There have been scandals such as the South Sea Bubble of 1720 and the Enron meltdown of 2001. But each has triggered measures to safeguard the interests of shareholders through disclosure requirements.

${ }^{78}$ Lamoreaux and Rosenthal, "Organizing middle-sized firms."

${ }^{79}$ By the standards of today's advanced economies, most companies of the early industrial era followed rather simple accounting practices; some did not even keep systematic records of financial transactions. Moreover, it was common for managers to manipulate their accounts with the purpose of misinforming shareholders or the wider public. See Naomi Lamoreaux, "Rethinking the transition to capitalism in the early American northeast," 90 J. American History 437-61 (2003). Nevertheless, there was an unmistakable movement toward advanced and standardized accounting methods, particularly in the most capital-intensive sectors. Not all corporations of the early industrial era raised capital in open markets. The shares of most early business corporations changed hands within small circles of closely connected individuals. But the shares of the largest companies tended to be traded widely.
} 
in the Middle East. In the early Islamic centuries, we saw earlier, Islamic law recognized only natural persons, and waqfs provided services supplied in western Europe increasingly by corporations. By themselves, these initial choices do not explain why, more than a millennium later, there existed no Muslim-founded corporations, or even unincorporated joint-stock companies. To solve this puzzle, we must identify chains of causation that blocked the development of complex organizational forms conducive to capital accumulation on a large scale. Insofar as opposing processes were present, a further challenge is to elucidate why certain social mechanisms proved decisive. ${ }^{80}$

Although the formative period of Islamic law would have constrained subsequent legal and organizational choices, in principle the barriers were not insurmountable. The centuries following the advent of Islam presented opportunities to reconsider the legal standing of groups and associations. One is the reality of more or less autonomous Muslim subcommunities, which conflicted with the ideal of undifferentiated communal unity. Another is the efflorescence of corporate life in western Europe, most critically, the organizational development of the traders who dominated trade between the Middle East and the West.

From the dawn of Islam, every generation of Muslims faced situations that made it convenient to assert a group identity less inclusive than that of the full community. The exigencies of daily life thus exposed the impracticality of keeping the ever-expanding global religious community undivided and undifferentiated. By the end of the seventh century, with Egypt, Syria, and Iraq in the Islamic fold, it was no longer realistic, if it ever was, to expect the full community to get involved in every issue. In practice, the individual Muslim's duty of "commanding right and forbidding wrong" would have to be limited to local matters. This implied that the community would be subdivided and also that subgroups would enjoy a measure of self-governance. Some social fragmentation was unavoidable.

If the shapers of Islamic legal discourse needed additional reality checks, they appeared through political divisions and rivalries. Just decades after Muhammad's death, even as Muslim thinkers continued to develop rationales for treating the community as undifferentiated, the Muslim community split into warring sects, and the Sunni-Shiite division was to endure. ${ }^{81}$ Meanwhile,

\footnotetext{
${ }^{80}$ On the methodology involved, see Peter Hedström and Richard Swedberg (eds.), Social mechanisms: an analytical approach to social theory (Cambridge 1998).

${ }^{81}$ For an overview of the divisions and subdivisions, see Patricia Crone, God's rule: government and Islam (New York 2004), chaps. 2, 4-9.
} 
converts maintained tribal, ethnic, linguistic, and geographic loyalties. Nor were these the only signs of persistent political division. Movements arose to obtain a privileged status for Arab Muslims, or at least for Muhammad's descendants, along with counter-movements defending the rights of nonArabs. ${ }^{82}$ Every Muslim empire has featured one or more politically dominant ethnic group, along with minorities dominant in one economic sector or another. Finally, after Muhammad no Muslim sovereign enjoyed legitimacy throughout the global community of Muslims.

In adhering to the ideal of a unified community and withholding legal rights from subcommunities, jurists and political theorists probably sought to deny divisions legitimacy, limit political fragmentation, and minimize gaps between ideal and reality. But established subcommunities need not have accepted the ideal of undifferentiation. Constituencies with a stake in forming a collective entity could have raised objections. For example, subcommunities might have developed movements to make states embrace the corporation, or some analogue, as a useful innovation.

Trends and circumstances that might have triggered an incorporation movement in the Islamic Middle East are not limited to ones within the region itself. Opportunities existed to benefit from advances in other societies, including the spread of corporations and the development of corporate law in the West. True, in the early Islamic centuries few Middle Easterners traveled to the West, which would have slowed the diffusion of new organizational technologies. But some did so, and western traders visited, or settled in, Muslim-governed commercial centers from Spain to Iran and beyond. There was also a steady flow of pilgrims to the holy sites of Christianity and Judaism, and incorporated groups, such as the Hospitallers, participated in the Crusades as both fighters and providers of charity. Thus, it was possible to learn about western organizational innovations without going far.

The most significant opportunity for learning about the western organizational trajectory presented itself with the overseas trading companies. Among other groups, Middle Eastern merchants, financiers, customs officials, and judges came into contact with chartered trading companies, at least indirectly; merchants who ventured to India and beyond encountered overseas companies also outside their own base. For lack of pertinent records, we are in the dark on how

\footnotetext{
${ }^{82}$ On racial divisions, see Bernard Lewis, Race and slavery in the Middle East: an historical enquiry (New York 1990), especially chaps. 3-5; and on group-based economic inequalities, Louise Marlow, Hierarchy and egalitarianism in Islamic thought (Cambridge 1997), especially chaps. 4, 6-7.
} 
Middle Eastern merchants viewed the companies. However, it should have been apparent that these companies benefitted from more or less centralized management and enjoyed unusual longevity. At the end of the seventeenth century Aleppo featured dozens of English "trading houses," each operated by a partnership regulated through the Levant Company. In contrast to the Islamic norm of short-lived business associations, some of these partnerships lasted decades, much like the repeatedly renewed Italian enterprises of an earlier period. Most houses employed wage-earning factors, whose tenure was indefinite. ${ }^{83}$ When an English, Dutch, or French merchant died overseas, his son or widow might take over, preserving his enterprise. ${ }^{84}$ Local merchants, whose own commercial operations were poised to dissolve after they died, must have realized that their foreign counterparts enjoyed capabilities that Islamic law, as usually interpreted, denied. Under the Islamic inheritance system, a successful merchant's wealth usually got dissipated after his death, unless he had endowed a waqf, which would restrict the use of his assets.

For their part, Middle Eastern statesmen could see that western negotiators of the trade treaties known as the "capitulations" attached enormous importance to the privilege of settling estates as they saw fit, without regard for Islamic inheritance rules. By the mid-fifteenth century the capitulations typically gave western consuls sole jurisdiction over the disposition of estates belonging to their countrymen. ${ }^{85}$ This right enabled western merchants in the Middle East to prepare enforceable wills that kept their estate undivided; if they died intestate, their own nation's inheritance regulations would apply. As trade with the West gained increasing importance, and Middle Easterners began losing market share to western traders in third markets, connections might have been sought between the content of the capitulations and foreign modes of organization.

Yet in the fifteenth through eighteenth centuries, a time when in the West commercial organization advanced by leaps and bounds, the Middle East produced no interpretation of these developments, or of their links to the capitulations, not even a factual report. No writings appeared,

\footnotetext{
${ }^{83}$ Ralph Davis, Aleppo and Devonshire Square: English traders in the Levant in the eighteenth century (London 1967), especially chap. 13.

${ }^{84}$ Elena Frangakis-Syrett, The commerce of Smyrna in the eighteenth century (1700-1820) (Athens 1992), 77.

${ }^{85}$ See art. 9 of the capitulations granted in 1497 to Florence, modeled after those granted in 1442 to Venice (reproduced by John Wansbrough, "Venice and Florence in the Mamluk commercial privileges," 3 Bull. of the School of Oriental and African Studies 509-23(1965)). The Ottomans reaffirmed these capitulations in 1528. See also art. 9, capitulations given by the Ottomans in 1535 to France (text in Necdet Kurdakul, Osmanl1 devleti'nde ticaret antlaşmalar1 ve kapitülasyonlar (Istanbul 1981), 41-48); and art. 9, capitulations given by the Ottomans in 1580 to England (text in J. C. Hurewitz, The Middle East and North Africa in world politics: a documentary record, $2^{\text {nd }}$ ed., 2 vols. i, (New Haven 1975), doc. 1).
} 
for instance, on the management of overseas trading companies, the consuls who represented foreign merchants, or foreign inheritance practices. This may appear as evidence of general apathy or ingrained traditionalism, especially when coupled with indifference to certain other advances. ${ }^{86}$ But attitudinal factors furnish at best a proximate explanation. The Middle East never sealed itself off from the West. It imported goods, which points to an understanding that the West produced useful things. It also borrowed military technologies, implying an appreciation of linkages between certain products and outcomes, such as western shipping technology and the changing balance of power in the Mediterranean. Nor was curiosity about the outside world deficient across the board. Where leaders sensed an advantage to learning about foreign practices or know-how, they managed to become informed. What requires explanation, then, is not Middle Eastern apathy per se. It is why, until the nineteenth century, no notable attempts were made to benefit from European advances in capital pooling, enterprise preservation, commercial management, and bookkeeping.

Two possible explanations for this selective apathy may be ruled out quickly. Islamic law was frozen, so goes a common supposition, by a "closing of the gate of innovation (ijtihā $d$ )" after a few centuries of development. In fact, Islamic law never became literally frozen. In principle fixed and all encompassing, it enjoyed flexibility as a matter of practice. For example, from an early period onward sundry fines and tolls were imposed, the tax system was changed, and rules governing the inheritance of agricultural land were revised, all by decree and with only the flimsiest basis in Islamic law. ${ }^{87}$ The other possibility is that the prevailing legal ethos made it impossible to accommodate fictitious persons without challenging the very core of Islam. Although the Qur'an would not provide any obvious help to a reformer seeking religious legitimation of corporate entities, with a modicum of imagination a person steeped in Islamic legal history could have found precedents for rudimentary forms of legal personhood. When asked whether property can legitimately be

\footnotetext{
${ }^{86}$ Bernard Lewis, The Muslim discovery of Europe (New York 1982), especially chaps. 3-5; and Bernard Lewis, What Went Wrong? Western impact and the Middle Eastern response (Oxford 2002), chap. 3, draws attention to various western developments that went unnoticed in the Middle East, inferring that there was a lack of curiosity in general. The failure to produce treatises on western science and dictionaries of European languages does indeed suggest incuriosity about the West. It shows also, however, that Middle Easterners considered it feasible to appropriate useful innovations without learning new languages or becoming broadly familiar with western cultures.

${ }^{87}$ Ömer Lütfi Barkan, "Türkiye'de din ve devlet ilişkilerinin tarihsel gelişimi," in Türk Tarih Kurumu (ed.), Cumhuriyetin 50. y1ldönümü semineri, especially pp. 70-83 (Ankara 1975); Richard C. Repp, "Qānūn and Sharī‘a in the Ottoman context," in Aziz al-Azmeh (ed.), Islamic law: social and historical contexts, 124-45 (London 1988); Sami Zubaida, Law and power in the Islamic world (London 2003), chap. 3; Colin Imber, Ebu's-Su'ud: The Islamic legal tradition (Stanford 1997), especially chaps. 2, 5-6.
} 
donated to a mosque, which is not a natural person, certain early jurists ruled in the affirmative. ${ }^{88}$ Likewise, the fourth caliph Ali (d. 661) reputedly ruled that the furnishings of Kaba, Islam's most sacred sanctuary, belong to Kaba itself. ${ }^{89}$ Such precedents might have served as justification for granting legal standing to a socially constructed entity.

\section{Lack of Demand for Organizational Innovation}

Thus, if some major constituency had pressured the Islamic court system to grant legal personhood to commercial organizations, religious obstacles could have been overcome. However, until very late no demand emerged for organizational changes of the sort that became routine first in Italy and then in northwestern Europe. Recall that in the West the unincorporated joint-stock company, and eventually the corporation, gained commercial applications only after generations of experimentation with simpler and more restrictive organizational forms, such as family firms and coordinated partnerships. Management patterns and business techniques evolved incrementally, as innovations induced further innovations. Could something have blocked the initiation of similar chains of innovation in the Middle East?

Islam's relatively egalitarian inheritance system stands out as a key source of unintended organizational stagnation. When the death of a partner voided an Islamic partnership, the costs of liquidation depended on the number of heirs. By requiring the division of estates among often numerous heirs, the Islamic inheritance system inadvertently raised the costs of liquidating a partnership prematurely. ${ }^{90}$ Merchants and investors could minimize the risk of premature liquidation by limiting the size and duration of their partnerships. The Islamic inheritance system would also have fragmented the estates of successful merchants, hindering the preservation of their businesses across generations. We know that until the nineteenth century Middle Eastern commercial enterprises remained generally small and short-lived, even as widely used western inheritance

\footnotetext{
${ }^{88}$ These jurists belonged to the Shafii and Maliki schools of law. See Hayreddin Karaman, Mukayeseli İslam hukuku (Istanbul 1974) 210.

${ }^{89}$ Hüseyin Hatemî, Önceki ve bugünkü Türk hukuku'nda vakıf kurma muamelesi (Istanbul 1969) 22-23.

${ }^{90}$ The Islamic rules of inheritance vary across the four Sunni schools of law, and there are greater variations between the Shii and Sunni legal traditions. Mallat, "From Islamic to Middle Eastern law," 708-15, ascribes the latter variations to differences between the Syrian variant of Roman law, from which the Sunnis borrowed, and Zoroastrian law, which influenced the development of Shii institutions. But each of the many interpretations of the Islamic inheritance system assigns shares to all members of a decedent's immediate family, and usually also to more distant relatives. Accordingly, the variations in question are of little consequence to the generality of the present argument.
} 
practices, notably primogeniture, facilitated enterprise preservation and growth in various parts of Europe. $^{91}$

It is the dynamic consequences that are critical here. Members of small partnerships will feel no great urge to develop sophisticated or standardized accounting methods. They will not seek improvements in bookkeeping of the sort that become necessary to facilitate communication and coordination among large numbers of shareholders. By the same token, the privilege of trading enterprise shares is of limited value to the owners of an ephemeral profit-making enterprise. The brevity of their commitments provides the liquidity that the shareholders of a long-term enterprise can obtain only through tradability. The upshot is that two fundamental advances of western organizational history-improvements in bookkeeping and the rise of stock markets-are conspicuous in pre-modern Middle Eastern history by their absence. ${ }^{92}$ Such advances did not even become an issue in the Middle East until the reforms of the nineteenth century.

An unintended consequence of the stagnation in business practices is that the business community could not even have contemplated using an organizational form akin to the corporation. Without double-entry bookkeeping, it is difficult to measure the net worth of a profit-seeking corporation, and bankruptcy procedures will almost certainly foster serious conflict. Moreover, in the absence of an infrastructure for trading shares, investing in a corporation will amount to relinquishing liquidity. Accordingly, Middle Easterners seeking to incorporate would have had trouble attracting investment. These difficulties help to explain why, until modern times, no known efforts were made to transplant the business corporation from abroad or, for that matter, to develop it from surviving records of Roman law.

To repeat, nothing in the evolving argument rests on the alleged fixity of Islamic law. Practices might have surged ahead of doctrine for a while, with individual kadis effectively recognizing and supporting organizational forms alien to strict Islamic teachings. With sufficient incentives for maintaining and refining the innovations, appropriate doctrinal changes would have followed, possibly in fits and starts. If no such sequence of events occurred, the reason lies in a lack

\footnotetext{
${ }^{91}$ Kuran, "Islamic commercial crisis." In principle, the inheritors of a partnership's assets could form a new partnership with surviving partners. The costs of negotiating a new contract rose, of course, with the number of heirs.

${ }^{92}$ On accounting practices in the pre-modern Middle East, see Omar Abdullah Zaid, "Accounting systems and recording procedures in the early Islamic state," 31 Accounting Historians Journal 149-70 (2004); Çiğdem Solas \& İsmail Otar, "The accounting system practiced in the Near East during the period 1220-1350 based on the book Risale-i Felekiyye," 21 Accounting Historians Journal 117-35 (1994); and Oktay Güvemli, Türk devletleri muhasebe tarihi, 4 vols., ii (Istanbul 1995-2001).
} 
of demand for organizational development — itself a reflection of missing institutional preconditions.

New institutions do not emerge individually, independently of other developments. Because the feasibility of any given innovation depends on the available institutional matrix, institutions develop as clusters, or "institutional complexes." ${ }^{93}$ The case at hand offers a dramatic illustration. The stagnation of business organization in general precluded evolution of a Middle Eastern variant of the business corporation, whether through indigenous innovation or borrowing from another legal system. When the need arose, Europe was able to adopt the business corporation because centuries of incremental and interlinked organizational improvements had installed its institutional preconditions. For the Middle East to develop a private corporate sector to match, say, the overseas companies, it would have had to develop also standardized bookkeeping and markets for trading shares. In other words, the path traversed in the West through myriads of organizational microinnovations would have had to be leapfrogged through a macroinnovation entailing an entire institutional complex. Indeed, when corporate law finally arrived in the Middle East, this happened as part of a massive organizational surge that included the introduction of stock markets, banks, modern accounting, and even new judicial systems. ${ }^{94}$

Over the period in question, when the Middle Eastern organizational menu stagnated, there was no lack of successful Middle Eastern merchants and financiers. Although we know of none who could bankroll a mission of global discovery or finance the military expeditions of a state, numerous case studies provide evidence of traders and moneylenders, Muslim and non-Muslim, who built huge households and financed major public services..$^{95}$ Taken as a whole, however, this literature confirms also that the organization of commerce and finance hardly changed. For centuries on end the supply

${ }^{93}$ Greif, Institutions, especially chaps. 5, 7 .

${ }^{94}$ Generally, Herbert J. Liebesny, The law of the Near and Middle East: readings, cases, and materials (Albany, N.Y. 1975), chap. 3; J. N. D. Anderson, "Law reform in Egypt: 1850-1950," in P. M. Holt (ed.), Political and social change in modern Egypt, 209-30 (London 1968). For specific organizational reforms, see Azmi Fertekligil, Türkiye'de borsa'nı̀n tarihçesi (Istanbul 1993), especially 18-26; Ali Aky1ldı, Tanzimat dönemi Osmanlı merkez teşkilâtında reform (Istanbul 1993), 129-33; Güvemli, Muhasebe tarihi, iii, chaps. 1-2, 4-5; Farhat J. Ziadeh, Lawyers, the rule of law and liberalism in modern Egypt (Stanford 1968), chaps. 1-3; Robert J. Tignor, "The introduction of modern banking into Egypt, 1855-1920," 15 Asian and African Studies 103-22 (1981); Timur Kuran, "The logic of financial westernization in the Middle East," 56 J. of Economic Behavior and Organization 593-615 (2005).

${ }^{95}$ For examples, see Thabit A. Abdullah, Merchants, Mamluks, and murder: the political economy of trade in eighteenth-century Basra (Albany, N.Y. 2001); Beshara Doumani, Rediscovering Palestine: merchants and peasants in Jabal Nablus, 1700-1900 (Berkeley 1995); Ronald C. Jennings, "Loans and credit in early $17^{\text {th }}$ century Ottoman judicial records: the Sharia court of Anatolian Kayseri, " 16 J. of the Econ. and Soc. Hist. of the Orient (1974) 168-216; and Abraham Marcus, The Middle East on the eve of modernity: Aleppo in the eighteenth century (New York 1989). 
of credit remained an activity directed by individuals and ephemeral partnerships; atomistic moneylenders did not give way to durable banks capable of mobilizing mass savings and making large loans. In eighteenth-century Aleppo or Cairo, the pooling of commercial resources generally took place through partnerships structurally identical to ones common almost a millennium earlier. Moreover, commercial businesses involving resource pooling across families rarely survived their founders; ordinarily heirs to business fortunes did not retain, let alone develop, organizations established by deceased relatives. ${ }^{96}$ This is why, perhaps, within Middle Eastern studies very few works exist on organizational dynamics, which is a vast subfield of European economic history.

One reason for the dearth of organizational innovation, we have seen, was the structural stagnation of commercial partnerships. A compounding obstacle to institutional change in the commercial sector was that successful merchants tended to convert their wealth into real estate, for reconversion into the corpus of a waqf. They did so for the very reason why founding waqfs gained enormous popularity among high officials: the weakness of private property rights. Prosperous merchants, like other wealthy groups, sought to shelter wealth within waqfs. ${ }^{97}$ The consequent outflow of mercantile wealth from the profit-oriented private sector must have limited even further the likelihood of partnerships gaining complexity, expanding in size, and paving the way for corporations. This is because the very merchants founding waqfs were those whose successes might have induced organizational adaptations to a larger scale of commercial activity. The availability of the waqf thus dampened the need for institutional innovations aimed at enabling larger and longerlasting commercial operations. Recall that in the West organizational advances accompanied growth in enterprise size and longevity.

\section{Structural Stagnation of the Waqf}

An unintended consequence of the waqf system, then, was the provision of opportunities that dampened incentives to develop organizational forms suitable to large and durable commercial

\footnotetext{
${ }^{96}$ In a developing data set, now consisting of over 4000 court cases between 1550 and 1692, all involving commercial and financial disputes litigated by Islamic courts in and around Istanbul, no evidence has emerged of a commercial organization more complex than those described in classical legal treatises. The same is true of similar data sets compiled by Gedikli, Osmanl1 şirket kültürü: XVI.-XVII. yüzy1llarda mudârebe uygulamas1 (Istanbul 1998); and Çizakça, Business partnerships.

${ }^{97}$ See Hanna, Making big money in 1600: the life and times of Ismail Abu Taqiyya, Egyptian merchant (Syracuse 1998), 125-26, 142, 147; and Meriwether, Kin who count, 23, 182-83, 193. There were also non-pecuniary motivations for forming waqfs. See Kuran, "Provision of public goods under Islamic law," 853-61.
} 
operations. Could the resources that flowed from the commercial sector to the waqf sector have induced structural changes in the latter? This question brings us to the dynamics of the waqf itself. As we already know, the waqf substituted for the corporation, with which it shared the capacity to outlive a founder. Yet the waqf did not generate, or metamorphose into, an organizational form akin to the corporation. Uncovering the underlying reasons is critical to explicating the absence of an Islamic variant of corporate law.

For answers, we can begin by identifying the key differences between the waqf and the business corporation. The waqf is not a profit-maximizing entity. An individual's share of a waqf's income is not transferable. No clear separation exists between the property of a waqf and that of its mutawalli. Finally, the waqf is not a legal person. In principle, each of these features could gradually have given way, if only in certain contexts, to corporate characteristics. Traditional rules might have been reinterpreted for the advantages of new organizational features.

From the start, the waqf was considered a vehicle for providing charity through the "immobilization" of wealth. Revealingly, one of the literal meanings of "waqf" is "to stop," another "to make dependent and conditional." 98 If nothing else, this characteristic precluded profit maximization in the manner of a commercial partnership. To be sure, the two goals need not have been in conflict. Maximizing the returns on the waqf's capital would also maximize its capacity to deliver charity. It is such logic, in fact, that in nineteenth-century England induced rules to strengthen the trustee's control over trust assets. ${ }^{99}$ Why, then, was the mutawalli's discretion not extended as a means of improving his ability to exploit waqf resources? Part of the explanation, no doubt, is that the state, whose legitimacy depended on waqf-delivered services, had a stake in the stability of waqfs. Greater mutawalli discretion, by boosting waqf profitability, would also increase the risks taken with waqf assets. During the formative years of the waqf system, statesmen might have reasoned that these risks outweighed the possible gains, thus helping to establish the observed tradition of limiting the mutawalli's discretion regarding the management of waqf assets.

Such thinking, if indeed it was a factor, would have carried less weight with respect to a "family waqf" (waqf ahli) meant to benefit primarily the founder and his descendants than to a

\footnotetext{
${ }^{98}$ Hans Wehr, A dictionary of modern written Arabic, ed. J. M. Cowan (Beirut 1980), 1091-94.

99 Trustees were allowed more discretion in selling and investing trust assets. Thus, prohibitions against investing in risky ventures were rescinded, and various remaining restrictions became default rules that founders could override contractually. See Harris, Industrializing English law, 147-52.
} 
"charitable waqf" (waqf khayrī) established to serve a broader constituency. In practice, the separation between the two categories was of degree than of kind; only a small minority of waqfs provided benefits confined to family members. ${ }^{100}$ Nevertheless, family waqfs are particularly relevant here. For one thing, where social services were not at stake the state lacked a compelling interest in limiting mutawalli discretion. For another, there is no obvious reason for the state to have prevented family waqfs from metamorphosing into family firms. Precisely because the resources of a strict family waqf serve the family itself, its mutawalli, a family member himself, would have been motivated to maximize its profitability. Moreover, his relatives, both as individuals and as a collectivity, had every incentive to develop institutions aimed at aligning his interests with theirs. Hence, the family waqf might have been the starting point for organizational innovations of the sort that led to the modern firm elsewhere.

Yet, in the public imagination the waqf was intertwined with delivering a designated service. This would have inhibited moves toward making this age-old institution serve strictly commercial purposes. The generic name of this universal source of conservatism is "compartmentalization." For a poignant example from the present, consider the task of making economic tradeoffs. When a retiree weighs her investment options, the act is widely considered legitimate. However, applying analogous risk-return tradeoffs to the allocation of medical resources is not. Most people are repulsed by the notion of withholding scarce physician time from terminally ill patients for the sake of assisting potentially curable children. Evidently, we make tradeoffs in certain contexts much more readily than in others. ${ }^{101}$ Vast inefficiencies result from this proclivity to avoid pairing related issues. ${ }^{102}$ Against this background, it is unsurprising that in the Middle East the legitimacy of profit seeking depended on the context, and that compartmentalization blocked lucrative advances in commercial organization. The only significant move in the direction of using the waqf as a form of business organization was the spread, after the fourteenth century, and primarily in Turkey and the Balkans, of the "cash waqf" - a waqf whose corpus consisted of cash. On the ground that the corpus must be

\footnotetext{
${ }^{100}$ The most ambitious quantitative study of the waqf system, that of Yediyıld1z, "Vak1f müessesesi," 28-33, on eighteenth-century Turkey, finds that only 7 percent were strictly family waqfs. On the distinction between the two types and further evidence, see Kuran, "Public goods under Islamic law," 855-60.

${ }^{101}$ Guido Calabresi \& Philip Bobbitt, Tragic choices: the conflict society confronts the allocation of tragically scarce resources (New York 1978); Alan P. Fiske \& Philip E. Tetlock, "Taboo trade-offs: reactions to transactions that transgress spheres of justice,” 18 Political Psychology 255-97 (1997).

${ }^{102}$ Timur Kuran \& Cass R. Sunstein, "Availability cascades and risk regulation," 51 Stanford Law Review, sects. 2-4 (1999); Cass R. Sunstein, Risk and reason: safety, law, and the environment (Cambridge 2002), especially chap. 2.
} 
immovable, segments of the learned class objected. ${ }^{103}$ However, following bitter struggles between generations of pragmatists and moralists, the lure of extending the wealth-sheltering advantages of the waqf to the holders of liquid wealth proved irresistible. Cash waqfs delivered a return on capital by lending at interest, itself controversial. A portion of them operated as moneylending operations for the benefit of individuals and families. Even here, however, the distinction between a waqf and a commercial organization was sustained. Whereas moneylenders outside the waqf sector could pool resources within financial partnerships, which they did for short periods and on a small scale, cash waqfs could not merge in order to supply credit on a larger scale. If for no other reason, they failed to develop into banks. ${ }^{104}$

The distinction between charitable and profit-making organizations might have eroded if the potential beneficiaries of organizational change enjoyed free organizational choice. In fact, groups with a stake in the status quo limited the available options. These groups included kadis, who were empowered to supervise waqfs, and risk-averse waqf beneficiaries, who would have felt threatened by organizational experimentation. Kadis were particularly motivated to resist moves to turn the waqf into a commercial organization. For one thing, they derived rents from their duty to enforce the founder's expressed will. For another, a commercialized waqf would base its decisions more on future opportunities than on past preferences. ${ }^{105}$ This reasoning admits the objection that kadis could have negotiated a Pareto-superior arrangement beneficial to everyone, including themselves. Two factors stood in the way. First, kadis had no organization capable of collective bargaining on their behalf. Second, the brevity of their tenures and the precariousness of their subsequent appointments encouraged them to make the best of existing opportunities. In sum, the supervisory authority of the kadis may have contributed to keeping waqfs from acquiring corporate features.

One such feature was free transferability, which a waqf lacked. A person's entitlement to the

${ }^{103}$ Jon E. Mandaville, "Usurious piety: the cash waqf controversy in the Ottoman Empire," 10 Int. J. of Middle East Studies 298-308 (1979); Çizakça, Philanthropic foundations, chap. 3; and Kuran, "Public goods under Islamic law," 873-75.

${ }^{104}$ Kuran, "Logic of financial westernization," 606-08.

${ }^{105}$ Waqf-related corruption is a major theme of Middle Eastern legal history. See Ahmet Mumcu, Osmanl1 devletinde rüşvet (özellikle adlî rüşvet), $2^{\text {nd }}$ ed. (Istanbul 1985), especially 295-96, 345-46; Ann K. S. Lambton, “Awkāf in Persia: 6th-8th/12th-14th centuries," 4 Islamic Law and Society 305 (1997); Megan Hibler Reid, "Exemplary of excess: devotional piety in Medieval Islam, 1200-1450," unpublished Ph.D. dissertation, Princeton University (2005), chap. 3.; Leonor Fernandes, "Istibdal: the game of exchange and its impact on the urbanization of Mamluk Cairo," in Doris Behrens-Abouseif (ed.), The Cairo heritage: essays in honor of Laila Ali Ibrahim, 203-22 (Cairo 2000); Halil İnalc1k, Osmanl1'da devlet, hukuk, adâlet (Istanbul 2000), 53-54. 
waqf's income could not be transferred to someone else. To take the simplest case, consider a cash waqf established to support the founder's family. His daughter could not sell her share of its income stream, not even to an existing beneficiary. Under the prevailing worldview, to do so would have crossed the line between charity and commerce. It would also have weakened the connection between intended and actual uses of the founder's resources. In eighteenth-century England, too, limitations were placed on the transferability of trust assets and entitlements, partly to preserve the character of a trust. ${ }^{106}$ The difference, of course, is that the waqf played a far greater role in the Middle East than its close western analogue did in the West, where the corporation was often the organizational form of choice. So efforts to maintain boundaries among economic sectors, or among organizational forms, were more consequential in the Middle East.

Legal personhood is another feature that failed to emerge. The mutawalli of any waqf, regardless of the movability of its corpus, bore personal liability for actions taken in fulfilling his duties. Aggrieved parties sued the mutawalli, not the waqf itself. ${ }^{107}$ There was no clear demarcation between assets of the waqf and those of its mutawalli. Kadis, who adjudicated disputes involving the mutawalli's exercise of his fiduciary duties, mitigated the consequent risks of serving as mutawalli. But this protection exacted a cost. Kadis effectively expected, and usually obtained, payment for their services - another reason why they supported the organizational status quo. Therein lies a plausible reason why the waqf sector saw no transition to legal personhood. A compounding factor is that legal personhood did not exist elsewhere in the legal system. The transition in question would have entailed a macroinvention, in the sense of requiring supportive judicial reforms.

\section{Role of the State}

An inquiry into the persistent simplicity of the organizational forms used by profit-seeking Middle Eastern enterprises must address more than the incentives and opportunities of individual subjects. States might have found it advantageous to help the business community develop larger, longerlived, and more complex organizations. In England and Holland, we saw, revenue-seeking states chartered overseas trading companies and endorsed their development through accommodating

\footnotetext{
${ }^{106}$ Harris, Industrializing English law, 152-53.

${ }^{107}$ The following cases of the Galata court offer examples: vol. 130, no. 91/2 (12 May 1683); vol. 131, no. 18/2 (10 September 1683); vol. 138, no. 18/4 (10 December 1686). See also Meriwether, Kin who count, 195.
} 
administrative and legal measures. State-supported organizational innovations need not have been limited to profit-seeking enterprises. Middle Eastern states might have tried to restructure a broad range of sectors in the interest of wealth creation, more efficient taxation, or political stability.

States do not benefit automatically from organizational innovations useful to private groups. Significantly, neither the English state nor that of the Dutch endorsed private organizational innovation indiscriminately. For centuries on end, each discouraged, even actively blocked, threatening innovations. In 1279, for instance, an English king issued a "Statute of Mortmain" to regulate and limit the transfer of real estate to the Church and other corporations. ${ }^{108}$ Until well into the nineteenth century, we have already seen, forming an English corporation was subject to government approval, granted selectively. ${ }^{109}$ Such facts underscore the political dimension of organizational innovation. Where and when the West saw organizational advances, the process involved negotiations, sometimes implicit, among various constituencies.

The Middle Eastern states established after the rise of Islam quickly discovered the advantages of treating certain groups as administrative units for taxation. Evidently rulers understood that private economic organization has broad implications. The case itself raises the question of why established administrative units, once recognized as collectivities, did not assert rights of selfgovernance and evolve into corporations. If the corporate form of organization was to emerge through indigenous means, these units might have provided a starting point.

From an economic standpoint, one of the weightiest cases consists of craft guilds (Ar., asnā $f$ or hirfa; Turk., esnaf or loncalar), which emerged around the fifteenth century. These guilds submitted to price controls and territorial restrictions, usually in return for state-supported monopolistic and monopsonistic rights. To varying degrees they enjoyed autonomy in setting membership requirements and selecting members. Although taxes were sometimes levied directly from individual members, this authority was often delegated to the head guildsman. ${ }^{110}$ Another common method of group taxation was tax farming, known in antiquity and, under Islam, used from an early period. It entailed auctioning off the right to "farm" a group's tax obligations. Competition

\footnotetext{
${ }^{108}$ Ernest D. Jones, “The Crown, three Benedictine houses, and the statute of Mortmain, 1279-1348," 14 Journal of British Studies 1-28 (1975).

${ }^{109}$ Harris, Industralizing English law, 282-85.

${ }^{110}$ Eunjeong Yi, Guild dynamics in seventeenth-century Istanbul: fluidity and leverage (Leiden 2004); Gabriel Baer, "Guilds in Middle Eastern history," in M. A. Cook (ed.), Studies in the economic history of the Middle East from the rise of Islam to the present day, 11-30 (London 1970); Timur Kuran, "Islamic influences on the Ottoman guilds," in Kemal Çiçek (ed.), Ottoman-Turkish civilisation, 4 vols., ii, 43-59 (Ankara 2000).
} 
among bidders, typically people knowledgeable about the group, served to maximize the ruler's tax revenue, which he received partly in advance, in the form of a downpayment. Ordinarily, the higher the taxable capacity of a tax farm, the larger the winning bid. ${ }^{11}$

Guilds could outlive their members. In other respects, however, they departed from a corporation. ${ }^{112}$ Though recommended by the membership, guild leaders were appointed by the state. True, as a matter of practice many guilds enjoyed substantial autonomy in the selection process; it was not unknown for the membership to dismiss a leader who failed to live up to its expectations, and when conflicts erupted between the guild and the state, the guild did not always yield. However, guilds that produced politically sensitive goods in places critical to political stability (for instance, the bakers and butchers of Istanbul) had leaders chosen directly by the government, usually from among military officers loyal to the sultan. ${ }^{113}$ To survive, therefore, guild leaders had to serve two masters at once. Representing their fellow guildsmen before the state, they had to work also to safeguard interests of the latter. The guilds were not, then, organizations capable of taking actions seriously at odds with state demands. They enjoyed self-rule only insofar as the state considered it helpful to revenue generation or harmless to political stability.

Another guild characteristic at odds with the corporate model involves dispute resolution.

111 All else equal, a tax farmer could appropriate more rents insofar as his demands enjoyed legitimacy. Accordingly, rulers imposed tax schedules for tax farmers to follow. These schedules limited what tax farmers could demand, but they also put the state's authority behind levies respectful of the specified limits. On tax farming practices by the Abbasids, see Frede Løkkegaard, Islamic taxation in the classic period, with special reference to circumstances in Iraq (Copenhagen 1950), 92-108; and by the Ottomans, Çizakça, Business partnerships, chap. 5; Linda Darling, Revenue-raising and legitimacy: tax collection and finance administration in the Ottoman Empire, 1560-1660 (Leiden 1996), chaps. 4-5, 8; and Metin M. Coşgel \& Thomas J. Miceli, "Risk, transaction costs and tax assignment: government finance in the Ottoman Empire," 65 J. of Economic History 806-2 1 (2005); Metin M. Coşgel, "Efficiency and continuity in public finance: the Ottoman system of taxation," 37 Int. J. of Middle East Studies 567-86 (2005).

112 There is a huge literature on whether "Middle Eastern" or "Islamic" guilds were corporations. The preponderance of the evidence points to a negative conclusion. They enjoyed far less autonomy than did their west European counterparts. See Claude Cahen, "Y-a-t-il eu des corporations professionelles dans le monde Musulman classique?" in A. H. Hourani and S. M. Stern (ed.), The Islamic city, 51-63 (Oxford 1970); Baer, "Guilds in Middle Eastern history," 17-22; Kuran, "Islamic influences on the Ottoman guilds," 46-53; Yi, Guild dynamics, 41-112, 237-42; and Said Amir Arjomand, "Transformation of the Islamicate civilization: a turning point in the thirteenth century?" 10 Medieval Encounters 130-31 (2004). For a recent rendition of the dissenting view, see Haim Gerber, State, society, and law in Islam: Ottoman law in comparative perspective (Albany, N.Y. 1994), 113-26. Gerber's argument hinges on variations among guild policies and privileges. Such variations are consistent, however, with heavy state supervision. The forms of autonomy compatible with state objectives could change over time, across space, and according to context.

${ }^{113} \mathrm{Yi}$, Guild dynamics, especially 70-81, 196-212. Keeping urban populations content has been a government objective throughout history. In the Ottoman Empire this goal undergirded a major principle of governance: provisionism. As Genç, Devlet ve Ekonomi, chap. 3, explains, provisionism entailed keeping the capital well-stocked with food, to deter uprisings. 
To solve their internal problems, guild leaders and members often went to state-appointed officials outside the guild system. And still another key difference is that the guilds lacked significant assets of their own; guildsmen owned or rented their shops and instruments as individuals. ${ }^{114}$ Some guilds formed common funds to provide mutual insurance, but the magnitudes seem small. The largest common fund noted in the most detailed study of Istanbul's guilds in the seventeenth century is that of the city's cauldron makers. In 1640, the fund held 76,000 aspers, which amounted to what a skilled construction worker would make in eight years. ${ }^{115}$ The fund's assets were too limited, then, to support even a single disabled member for a decade. ${ }^{116}$

Nevertheless, the guilds might have acquired more autonomy over time. If this did not happen, a key reason must lie in political conditions. At the time of their emergence, Anatolia was in turmoil, with many weak statelets vying for authority and frequently shifting boundaries - much as in western Europe during the half-millennium that saw the proliferation of the earliest religious and urban corporations. Had the turmoil continued, the consequent political and legal vacuum might have permitted the guilds to assert greater autonomy and become organizations analogous to corporations. However, the Ottomans managed not only to unite Anatolia but to extend their authority over major commercial centers in the broader region. They opted to use the guilds to serve state goals. They saw no reason to grant the guilds legal personhood, or the means to manage their resources centrally, or the right to expand their operations at will.

To turn to the case of tax farms, they were formed by the state, rather than tax constituencies themselves. The state was free to alter their boundaries and to switch to direct taxation through salaried officials. Where possible, it opted for direct taxation, resorting to tax farming only where the transaction costs of direct collection were exceptionally high. ${ }^{117}$ Of course, a tax farm could provide its operator a financial base for challenging state authority. Also, a state-created tax constituency could develop a common identity conducive to collective opposition. Aware of these

\footnotetext{
${ }^{114} \mathrm{Yi}$, Guild dynamics, 90-95, 177-79.

${ }^{115} \mathrm{Yi}$, Guild dynamics, 61-62, 85. In 1640 the daily wage of a skilled construction worker was 29.5 aspers [Süleyman Özmucur \& Şevket Pamuk, "Real wages and standards of living in the Ottoman Empire, 1489-1914" $62 \mathrm{~J}$. of Economic History 301 (2002)]. The calculation assumes that a worker works 300 days a year.

${ }^{116}$ This common fund was organized as a cash waqf. Like other cash waqfs, it lent money at interest. Given that its capital was formed through the pooling of cash supplied by dozens of guild members, it amounted to a type of bank. But the fund did not trigger a banking revolution. It did not grow significantly, and the innovation was not copied widely.

117 Coşgel \& Miceli, "Transaction costs and tax assignment," find that in the Ottoman Empire direct taxation by the central government was less likely when the cost of measuring the tax through appointed agents was high.
} 
risks, successive sultans kept the tax farm period short enough to enable frequent rotation among tax farmers; depending on the sector, the term was one to twelve years. They also adjusted farm boundaries and suppressed tax farmers showing signs of acquiring a political base. From the start, then, tax farming served as an instrument of state power rather than of collective empowerment on the part of subcommunities. It was unlikely to ignite an incorporation movement, because the state watched for signs of collective action liable to weaken its control over revenue streams.

All else equal, the longer the tax farm period, the greater the bids of potential tax farmers. But as the period lengthened, the probability of the winner gaining political autonomy grew accordingly. The Ottoman state thus faced a risk-return tradeoff. How it resolved that tradeoff could change in response to a greater risk from another source. The record bears this out. In 1695, in the face of mounting budget deficits and an impending military defeat, various short-term tax farms were converted into life-term tax farms (malikanes). As intended, the amount required to purchase a tax farm, including the down payment, was now higher. ${ }^{118}$ Consistent with the foregoing logic, Ottoman tax farmers steadily gained political clout and began claiming the right to bequeath farms to their descendants. Pressing revenue needs made state officials turn a blind eye to these developments, but only for a while. They lay in wait for an opportunity to curb the autonomy of tax farmers. In 1812 , the government started to take over the management of tax farms. ${ }^{119}$

This episode illustrates how the Ottoman state blocked political and economic decentralization. Even more interesting is the accompanying interruption of a process of organizational innovation. To meet the payments required to win auctions, tax farmers had taken to forming partnerships intended to last for the duration of the farm, possibly decades. ${ }^{120}$ Predictably, personal emergencies and other business opportunities prompted certain partners to withdraw from established tax farms by selling their remaining rights. Under the strict interpretation of prevailing Ottoman laws, such sales were illegal; the existing partnerships would have had to disband and be renegotiated. However, tax farmers and the state had a common interest in ensuring the viability of the new system of transferability. The former benefitted through higher share prices, the latter through the consequent rise in bids. A formally illicit yet officially tolerated market in tax farm shares thus began to flourish. Another induced innovation involved management. Finding it efficient

\footnotetext{
118 Bidders specified a down payment and a schedule of periodic payments.

119 Çizakça, Business partnerships, 184-86.

120 The life of one partner, the principal, determined the farm's duration.
} 
to institute a rotating division of labor, partners started taking turns as managers. ${ }^{121}$

Just as western organizational advances fed on themselves, so these developments might have placed the tax farm sector on a path of sustained organizational modernization. The rising incidence of western share transfers had led to organized capital markets; through an analogous pattern, the spread of transactions involving tax farm shares might have generated formal stock markets. The managerial rotation system imposed transaction costs, so by inducing the hiring of professional managers it might have brought about a separation of ownership from management. A demand for indefinitely lived partnerships might have followed, for in a professionally managed partnership with changing owners "lifetime ownership" becomes a meaningless concept. One might also have seen advances in bookkeeping. In brief, the Ottoman tax farming sector was on its way to developing advanced techniques of economic management, discovering an indigenous form of the joint-stock company, and establishing the preconditions for the business corporation. Conceivably, tax farmers themselves might have formed the first corporations of the Islamic Middle East.

The described dynamic, had it run its course, would have been an unintended consequence of a state policy motivated by immediate revenue generation. Alas, the Ottoman state was unconcerned with the organizational opportunities of private investors, except insofar as they affected its ability to govern in transparent ways. For fear of revenue losses in the short run, it opted not to assist innovations but to inhibit them. In the early nineteenth century, worried about the growing difficulty of keeping track of ownership records and afraid of losing the right to re-auction tax farms, authorities restricted the number of shares that any given tax farm could issue. Then they took to confiscating tax farms and switching to direct taxation. ${ }^{122}$ These moves alleviated the pressures for further organizational innovation, precluding the pursuit of opportunities for economic modernization. Private financiers in general, and the shareholders of tax farms in particular, were too weak to resist the state-imposed restrictions. Had organizational development not lagged elsewhere in the social system, the outcome may well have been different. ${ }^{123}$

121 Çizakça, Business partnerships, 159-78.

${ }^{122}$ Çizakça, Business partnerships, 184-86. In taking over the management of tax units, the Ottoman government started selling "profit shares" (esham). In the course of the nineteenth century these turned into tradable bearer shares. Revealingly, the Ottoman state, having arrested the development of a market for privately-issued shares, allowed the trading of government-issued shares.

${ }^{123}$ That pre-modern Muslim-governed states, including the Ottoman state, had the power to block various private initiatives has been noted widely by scholars searching for the origins of authoritarian governance patterns. Influential examples include Şerif Mardin, "Power, civil society and culture in the Ottoman Empire," 11 Comparative 


\section{The Limited Autonomy of Minorities}

In searching for possible indigenous paths to the corporation, we need to consider one final economically important case: religious minorities. At the dawn of Islam, Jewish and Christian communities were already organized under rabbis and priests, and they possessed collective identities. Under Islamic rule, successive regimes pursued policies that preserved communal distinctions. As noted above, in Islamic courts a non-Muslim litigant was almost always identified as a member of his religious community. In general a Christian or Jew was also required to wear clothes intended to mark him off as a member of a non-Muslim community with distinct rights and responsibilities. ${ }^{124}$ Muslim rulers granted internal autonomy to Christian and Jewish communities, but only insofar as this was convenient. Whereas minorities were free to adjudicate internal civil lawsuits on their own, the Islamic courts had sole jurisdiction over all criminal cases.

It is one thing to possess a right, quite another to exercise it. Although non-Muslims were free to adjudicate disputes with one another outside the Islamic legal system, as individuals they were free also to seek justice from a kadi, whose decision would trump that of a non-Muslim tribunal. This choice of law made minorities appeal frequently to Islamic courts, if only to obtain binding decisions. Hence, it had the effect of drastically limiting effective communal autonomy. In any case, civil cases involving at least one Muslim had to be tried by Muslim judges. ${ }^{125}$ Non-Muslim interactions with Muslims took place within an Islamic institutional framework. Accordingly the very mechanism that kept Muslims from developing the corporation constrained institutional evolution also within non-Muslim communities.

Nevertheless, community-specific state policies created other opportunities for organizational development. The taxation of minorities offers a case in point. Over the ages, sultans often found it advantageous to relegate tax collection to a communal leader abreast of his constituents' capacity

Studies in Society and History 258-81 (1969); and Saad Eddin Ibrahim, "Civil society and prospects for democratization in the Arab world," in Augustus Richard Norton (ed.), Civil society in the Middle East, 2 vols., i, 27-54 (Leiden 1995). The present argument extends that literature by proposing social mechanisms that delayed organizational development outside the state sector.

${ }^{124}$ See, generally, Benjamin Braude \& Bernard Lewis (eds.), Christians and Jews in the Ottoman Empire, 2 vols. (New York 1982); Macit M. Kenanoğlu, Osmanl1 millet sistemi: mit ve gerçek (Istanbul 2004), especially 245-77; and Mark R. Cohen, Under crescent and cross: the Jews in the Middle Ages (Princeton 1994), especially 88-103, 125-28.

${ }^{125}$ On the legal rights of minorities and their effects on legal evolution both within minority communities and the wider social system, see Kuran, "Economic ascent," sects. 5-13. 
to bear taxes. For Jewish and Christian communities, but also tribal Muslim communities, this leader was frequently a religious authority. The communal leader would negotiate a tax for his "contribution unit" (under the Ottomans, avarizhane) and then apportion the burden among the unit's households, presumably on the basis of private information about ability to pay. In negotiating with the sovereign he would often seek to minimize his community's tax burden through tricks such as doctoring birth registers and understating production capacity. ${ }^{126}$ With varying success, rulers tried to co-opt communal leaders to serve as state agents; when results were unsatisfactory, they would alter the tax collection policy, having their officials collect directly from individuals. Evidently, communal autonomy had its limits. One may infer that the state would have resisted any move to assert genuine corporate power o behalf of religious minorities. Until the nineteenth century, the era of nationalist awakenings, it was generally powerful enough to prevail.

That minority communities would be recognized as groups only insofar as the state expected to gain is abundantly clear from a series of dealings, in the late sixteenth century, between the Jews of Jerusalem and Ottoman authorities. The former sought to lease a plot for use as a cemetery. Because no collective entity had standing before the courts, they could not do so as a community. Three wealthy individuals stepped forward to lease land in their own names, and as an individual each assumed personal responsibility for paying one-third of the rent. The Islamic court that registered the thirty-year lease did not treat the trio as a representative body; each renter was addressed as "a member" of the Jewish community. ${ }^{127}$ This is significant. Overcrowding in existing cemeteries could not have been a matter of primary concern to the state. Authorities would have seen no particular need to grant Jews legal recognition as a community in this particular context.

The same authorities faced different incentives when debt restitution or tax collection was at stake. Around the same time, in 1596, an impoverished Jew appeared before a Muslim judge to complain that his community had ordered him to repay a share of a debt incurred for its collective benefit. Challenging the requirement on legal grounds, he testified that communities lacked standing before the law. Although the plaintiff was interpreting Islamic law correctly, the judge made him pay

126 Harold Bowen, “Awārid,” Encyclopaedia of Islam, 2 ${ }^{\text {nd }}$ ed., i (Leiden 1960), 760-61; Linda Darling, Revenue-raising and legitimacy: tax collection and finance administration in the Ottoman Empire, 1560-1660 (Leiden 1996), 100-08.

${ }^{127}$ Amnon Cohen, "Communal legal entities in a Muslim setting, theory and practice: the Jewish community in sixteenth-century Jerusalem," 3 Islamic Law and Society 77-79 (1996). 
his share. ${ }^{128}$ In this context, therefore, the Jewish community was effectively granted legal personhood. Why the difference between this case and that of leasing a cemetery? The creditors of the Jews included people of all faiths, but most were Muslims, including high officials. For this reason alone, the restitution of Jewish debts was a matter of concern. The personal needs of politically prominent creditors aside, both intercommunal harmony and the smooth functioning of financial markets benefitted from the orderly repayment of debts. It thus served the state to authorize a communal leader to allocate debt burdens among his constituents. As with taxation, these leaders possessed the local knowledge necessary to exact resources; the state's own agents did not.

Insofar as rulers facilitated or promoted communal autonomy for non-Muslims, they provided organizational rights formally denied to Muslims. In an Islamic court a Muslim litigant was never designated as a member of a Muslim subcommunity — a Shiite, a Bektashi, or adherent of the Maliki school of law. When Muslim groupings were recognized for purposes of efficient governance, as with tax farming, the consequent administrative divisions were treated as temporary. If minorities were permitted to form effectively permanent communal organizations, the reason must have been that these entities were relatively less threatening to political stability. Any non-Muslim community that sought to use its autonomy as a vehicle for resistance to the incumbent regime, or for broad institutional reform, could expect resistance from Muslims, on the ground that Islam, or Islamic territory, was under threat. Mobilizing the masses against an organized Muslim opposition would have been more difficult.

To recapitulate, pre-modern Muslim rulers understood the uses of communal autonomy. But they allowed self-governance selectively and in limited contexts. Precisely because of the region's organizational history, the communities themselves lacked the means to assert broader communal powers.

\section{Conclusions}

It is time to connect the dots. In the early Islamic centuries the conditions governing organizational

\footnotetext{
${ }^{128}$ Cohen, "Communal legal entities," 80 . Anticipating this sort of challenge, Jewish leaders typically cloaked their communal debt agreements in a legal fiction. Specifically, they listed all members of the community as co-debtors, whether or not they had consented. In claiming implicitly that every member had agreed to liability, they met the requirement that only natural persons have standing before the law. For their part, by accepting this fiction, kadis effectively recognized the existence of a collective entity empowered to impose its will upon individuals, though only in contexts selected by a higher authority.
} 
evolution differed between the Islamic Middle East and the West. Born in a society torn by endemic tribal warfare, Islam developed a legal system averse to subdividing Muslims politically. This system was enforced over a wide area and in basic respects uniformly, which dampened the urge to develop non-state organizations akin to the Roman corporation. Legal personhood, essential to the development of large and complex self-governing organizations outside the purview of the state, was thus excluded from Islamic law early on. Meanwhile, the Roman concept of a corporation was having a profound influence on legal evolution in western Europe. In a political environment marked by weak central authority, a wide array of collectivities became corporations and took to governing themselves autonomously, according to self-chosen rules. Thus, the initial organizational divergence between the Middle East and the West reflects legal choices made, in both regions, during Islam's formative period, the seventh to tenth centuries.

That the corporation was absent from the Middle Eastern organizational menu until the nineteenth century is not attributable solely to initial conditions or early choices. In the course of the second millennium, as corporations proliferated in the West, and eventually saw use by profitseeking enterprises, three distinct mechanisms kept the Middle East organizationally lethargic in certain areas that would become critical to economic performance during the Industrial Revolution.

The first involves the persistent simplicity of partnerships. Until quite late, Middle Eastern producers, merchants, and investors saw no need for standardized bookkeeping, or professional management, or free transferability of shares. This is because the Islamic inheritance system dampened incentives to form large and long-lived partnerships; and the consequent stagnation in enterprise size and longevity obviated institutional innovations aimed at dampening new or rising transaction costs. The business community had long been familiar with owner shielding, or limited liability, a feature useful even to two-person partnerships of short duration and obtainable at will through contract. However, profit-seeking groups did not develop entity shielding, which requires new law. This is because entity shielding is useful especially to long-lived enterprises, which they did not form. In short, the Islamic legal system did not generate various organizational features and techniques characteristic of economic modernization. As a byproduct of this institutional stagnation, the region failed also to develop the preconditions for transplanting the business corporation from abroad. Absent a constellation of fundamental legal reforms, there was no practical way for profitseeking groups to incorporate on their own.

The second mechanism of retardation worked through the supply of social services. In the 
course of a millennium when western charities, religious bodies, universities, and cities adopted the corporate form of organization, in the Middle East analogous functions came to be served primarily by the waqf, the Islamic analogue of the trust. Like a corporation, a waqf could outlive its founder. But it was not considered self-governing. Required to follow the founder's directives, its mutawalli lacked the discretion necessary for maximizing profitability of the corpus. If such discretion did not emerge over time, and waqfs failed to become self-governing and profit-maximizing organizations, a basic reason is that vested interests stood in the way. Specifically, reforms would have threatened the rents that judges derived from their duty to monitor mutawallis. A compounding obstacle to restructuring was the lack of an Islamic corporate structure outside the waqf sector. Because the court system was unaccustomed to legal persons, anyone trying to incorporate a waqf would have had to start by familiarizing judges with the concept and gaining their acceptance for its specific applications.

The third mechanism contributing to the observed organizational divergence involved states. Notwithstanding early Islam's aversion to factionalism, pre-modern Muslim rulers were prepared to treat collectivities as groups. Thus, they accorded de facto recognition to guilds and religious minorities, though on a selective and limited basis. There was no insurmountable obstacle, then, to the treatment of Middle Eastern or Muslim traders as groups. Had they been organized within merchant guilds or under consuls, and possessed the organizational know-how to form large and durable business enterprises, local regimes might have been inclined to assist their further development. In fact, merchants developed no permanent organizations. As late as the early nineteenth century, they formed small associations for temporary missions. This lack of organizational longevity must have dampened incentives to grant them a collective identity. It would also have limited incentives to assist their organizations through institutional innovations such as legal personhood and entity shielding. In the West the merchant groups that obtained corporate charters were already organized in structures with deep historical roots. States aided their organizational development in the interest of benefitting through taxes and loans.

We now have a general, if necessarily tentative, explanation for why Abdülmecit, contrasting his shrinking empire with the dominant states of the global economy, noticed a vast difference in the organization of business. For at least a millennium, the West had been developing ever newer organizational forms to suit a panoply of social needs. Its producers, merchants, and investors had learned how to form, operate, and preserve large and structurally complex organizations. States had 
contributed to these advances for their own ends. As for Abdülmecit's own corner of the world, the organizational options available to private businesses operating under Islamic law hardly differed from those available in the Middle Ages. Previous Ottoman sultans had not encountered transformations worth stimulating for their own benefit. Moreover, where such transformations had started to unfold, as when the shift to life-term tax farms gave rise to long-term partnerships with tradable shares, his predecessors had seen not opportunities for spiraling social gain but immediate fiscal and political threats.

There is no reason to think of Islamic law as inherently unchangeable. True, the Islamic heritage harbors elements that promote conservatism, and generations of Muslims have invoked scripture and perceived precedents to block institutional change. However, reformers have been able to draw legitimacy from the very same sources. Had a significant demand emerged for expanding the organizational options of the mercantile community, religious sensibilities would not have posed an impregnable barrier. That is why this paper has departed from the "essentialist" interpretations of an earlier generation, traveling great lengths to uncover why various possible paths to the corporation were clogged. For Claude Cahen, S. M. Stern, and their followers, the lack of an Islamic corporate culture was a defining feature of Islamic civilization. Having located it, they refrained from exploring why it endured for centuries on end. ${ }^{129}$

The most telling reason to reject the essentialist interpretation lies in the legal reforms that followed Abdülmecit's initiative, all across the Islamic world. By the early twentieth century, in a period of wide-ranging reforms engendered by political and economic crises, the corporation had been transplanted to the legal systems of the Middle East. Nowhere did the recognition of legal personhood or laws to provide entity shielding generate reactions in the name of Islamic purity. Today's Islamist movements do not want to limit legal standing to natural persons, and they are not bothered by organizational longevity. Although certain institutions of early Islam prevented the emergence of the corporation from from within Islamic civilization, once borrowed from abroad along with supporting institutions, it got absorbed into local legal systems and now faces no further resistance.

${ }^{129}$ Cahen, "Corporations professionelles"; Stern, "Constitution of the Islamic city". 